[Notes to printer: 1) $\rfloor$ (vertical line with inferior point beneath), as on f. 20 line 5 down after $3^{\text {rd }}$ word, should be replaced throughout by a vertical line with a curve or saucer underneath it. This symbol is not available on my computer, but can be seen in the attached scan from a printed page, lines 3 and 5 down (lines 1 and 3 of Latin quotation; to see properly please enlarge to 100\%). 2) (brevis) may need care when on same Greek vowel as accent or breathing or both.]

\title{
APPIAN THE ARTIST: RHYTHMIC PROSE AND ITS LITERARY IMPLICATIONS*
}

\section{INTRODUCTION}

If we had no idea which parts of Greek literature in a certain period were poetry or prose, we would regard it as our first job to find out. How much of the Greek prose of the Imperial period is rhythmic has excited less attention; and yet the question should greatly affect both our reading of specific texts and our understanding of the whole literary scene. By 'rhythmic' prose, this article means only prose that follows the Hellenistic system of rhythm started, it is said, by Hegesias, and adopted by Cicero and by many Latin writers of the Imperial period. Estimates of how much Greek Imperial prose is rhythmic have long varied drastically. Some experts suggest that all or much artistic Greek prose in the period is rhythmic, others that what little there is fades out after the first century AD, as part of the victory of Atticism. There has been fairly little substantial work on rhythmic prose in the first three centuries AD for over fifty years (more on accentual prose from the fourth). The object of this article is to investigate a large part of one author's work thoroughly, and to establish that that part is rhythmic. It will also aim to show how 
that conclusion should greatly affect our whole conception of the author as a writer, and our reading of his every sentence. ${ }^{1}$

* For crucial advice in §II, I am greatly indebted to Professor Andrew Steane (Department of Physics, Oxford). I am also grateful to $C Q$ 's two readers for their wise suggestions.

${ }^{1}$ Contrasting views on extent of rhythmic prose in Imperial Greek: Ed. Norden, Die antike Kunstprosa vom VI. Jahrhundert v. Chr. bis in die Zeit der Renaissance (2 vols., Leipzig, 1898), 2.918-22, cf. e.g. 1.423-7; U. von Wilamowitz-Moellendorff, 'Asianismus und Atticismus' [1900], Kleine Schriften 3 (Berlin, 1969), 223-73, at 257-9; R.L. Hunter, A Study of Daphnis \& Chloe (Cambridge, 1983), 85 (though 'rhythmical' is not used as narrowly as 'rhythmic' here); M. Winterbottom, 'On ancient prose rhythm: the story of the dichoreus', in D. Obbink and R.B. Rutherford (edd.), Culture in Pieces: Essays on Ancient Texts in Honour of Peter Parsons (Oxford, 2011), 262-76, at 264. Hunter at 84-5 on Longus and Winterbottom at 263-5 on developments in Greek are among the most significant contributions in relatively recent times. Earlier, an especially important general treatment is the work of A.W. de Groot: A Handbook of Antique Prose-Rhythm I (Groningen, The Hague, Leipzig, 1919); Der antike Prosarhythmus I. Zugleich Fortsetzung des Handbook of Antique Prose-Rhythm (Groningen, 1921); La Prose métrique des anciens (Collection d'études latines II, Paris, 1926). Particularly valuable as a treatment of a single author (though he includes comments on others) is St. Heibges, De clausulis Charitoneis (Diss. Münster; Halle, 1911), supervised by W. Kroll. On the accentual system which begins in the fourth century see W. Hörandner, Der Prosarhythmus in der rhetorischen Literatur der Byzantiner (Wiener Byzantinische Studien 16, Vienna, 1981), esp. 5171; Chr. Klock, Untersuchungen zu Stil und Rhythmus bei Gregor von Nyssa. Ein Beitrag zum 
Appian may seem an unexpected choice: his style and his manner of writing have not on the whole been greatly appreciated, and the question whether he is rhythmic has never to my knowledge been considered. Recent scholarship has realized how much Appian designs and thinks about his work; the realization needs to be extended to the specifics of his writing, as would seem obvious if we were considering Sallust, Tacitus or Thucydides (Appian's foremost model). The study should in principle be of significance for Appian, and for the period more widely; the detailed discussion will offer some means of establishing what other Imperial prose is rhythmic, and give us pointers to reading that rhythmic prose with stylistic sensibility. ${ }^{2}$

Rhetorikverständnis der griechischen Väter (Beiträge zur klassischen Philologie 173, Frankfurt am Main, 1987), 219-300.

${ }^{2}$ Some typical comments on Appian's style: E.L. Bowie, 'Appian', in P.E. Easterling and B.M.W. Knox (edd.), The Cambridge History of Classical Literature I Greek Literature (Cambridge, 1985), 707-9, at 709: 'stylistically undistinguished, but . . . far from unreadable'; similarly B.C. McGing, “Appian's “Mithridateios””, ANRW 2.34.1 (1993), 496-522, at 520; M. Weißenberger, 'Das Imperium Romanum in den Proömien dreier griechischer Historiker: Polybios, Dionysios von Halikarnassos und Appian', RhM N. F. 145 (2002), 262-81, at 271, 'der für Appians Stil ungewöhnliche Aufwand an stilistischem Schmuck . . (Trikolon, Parallelismus, Homoioteleuton)' (on Proem 41; this certainly gives a misleading impression: for the superlatives cf. e.g. Hisp. 318, B Civ. 2.621, for the three features e.g. Hisp. 197, Hann. 102). More responsive to Appian's writing is an article by a scholar who works especially on Latin poetry: J. Henderson, 'Three men in a vote: proscription and the power of the text (Appian, Bellum Civile 4.1.1-6.51)', Histos 1 (1997), 93-112. Cf. also E. Potz, 'Ficta, non facta dicere und trotzdem die Wahrheit berichten. Caesar, Bellum civile 1, 43-87 und Appian, Emphylia 2, 42 
The study of Greek prose-rhythm has been diverted by consideration of rhythm in the times before Hegesias, a subject intrinsically much more obscure. There are more hopes of success in pondering whether or not individual Imperial authors adhere to a system which is essentially known than there are in working out a rhythmic system for each Classical author. The endings that will be taken as rhythmic in this article are the standard $-\cdots-$ . Any long can be resolved except for the last, which can be replaced by a breuis in longo; the last syllable, whether or not thus lengthened by quasi-metrical pause, is simply marked as long in the examples below. Two other endings (their resolved forms included) are not here classed as rhythmic, that is, as part of this rhythmic system: $\cdots--\cdots$ and $-\cdots$. The former is not supported as rhythmic by Latin practice with atque + consonant or by Latin theorizing. The matter is not of crucial importance, since this ending comes much less often than the second. It does, though, form a higher proportion of apparently unrhythmic endings in Appian than in pre-Hellenistic prose, so that regarding it as unrhythmic will make it harder to show that Appian was rhythmic (since there will be a smaller difference between Appian and pre-Hellenistic prose

f.', Grazer Beiträge 21 (1995), 85-94, at 89 and 91-2; and already H. Strebel, Wertung und Wirkung des Thukydideischen Geschichtswerkes in der griechisch-römischen Literatur. (Eine literargeschichtliche Studie nebst einem Exkurs über Appian als Nachahmer des Thukydides) (Diss. Munich; Speyer am Rhein, 1935), 92: ‘Appian . . . kann wenigstens nach der formalen Seite keineswegs als reiner Compilator angesehen werden, der hinter seinen Quellen verschwindet' (73-92 for Appian and Thucydides). On shape and thought in Appian's work see n. 23 below; an early aside in the right direction: J.P.V.D. Balsdon, review of P. Meloni, $I l$ valore storico e le fonti del libro macedonico di Appiano (Rome, 1955), JRS 46 (1956), 199-201, at 200: 'Appian (who is commonly assumed to have had no mind of his own)'. 
in the number of apparently rhythmic endings). For that very reason, it would be prudent for now to regard it as unrhythmic. The second rhythm, ----, is in shape completely unlike the singleshort sequences here regarded as rhythmic; the resolved forms it would bring with it—and it would be still more anomalous to admit the ending but exclude its resolutions-mark out the double-short character that it would possess. (Note also the worries at Cic. Orat. 224, Quint. Inst. 9.4.97 [in Russell's text], 101.) The sequence accounts, with its resolutions, for most unrhythmic endings. But if we did regard it as rhythmic, that would not create a problem for the argument to come. The argument could simply be altered from presenting unrhythmic prose as higher in its proportion of unrhythmic endings than rhythmic prose: it would instead present it as higher in its proportion of a particular ending which was on this view rhythmic in rhythmic prose but was less used there than in unrhythmic prose. ${ }^{3}$

\footnotetext{
${ }^{3}$ On prose before Hegesias note recently S. Usher, 'Eurhythmia in Isocrates', $C Q$ n.s. 60 (2010), 82-95. It seems reasonable to accept $-{ }^{-}$as part of the rhythmic system, though it is less common than the other three endings: it is strongly supported by Cicero's use of atque + consonant to obtain it (cf. G.O. Hutchinson, 'Rhythm, style, and meaning in Cicero's prose', $C Q$ n.s. 45 [1995], at 485-6). Longin. 39.4 in fact suggests its place in the system (cf. D.A. Russell, 'Longinus' On the Sublime: Edited with Introduction and Commentary [Oxford, 1964], 175); Quint. Inst. 9.4.107-8 quotes it from Cicero (Phil. 2.63) and finds it acceptable in delivery, despite anxieties about poetry. Even De Groot (n. 1, 1921), 66, notes that it occurs twice in the inscription of Antiochus I of Commagene and is somewhat more common in Cicero than in unrhythmic prose; he grudgingly thinks it permitted in rhythmic prose if not actually sought. The overall case would not be affected if the ending were accounted unrhythmic.
} 
In Latin prose, the practised reader can usually decide from a few pages whether an author is rhythmic; it appears to be much harder in Greek prose. The system was devised to suit Greek. In unrhythmic Latin - - - occurs still more frequently than in Greek, thanks to various linguistic changes in Latin and Proto-Italic; and the standard Latin pattern of a final verb makes all the more conspicuous the efforts required of Romans to sustain rhythmic writing. With Greek prose, it is easy to be unsure; I have myself changed my mind more than once on whether Appian is rhythmic. These difficulties prompt us to see whether quantification will help. Some past use of figures in this area makes one nervous of employing statistics; but we have a simple question, and can produce firmly differentiated masses and apply straightforward methods. ${ }^{4}$

Particular problems of prosody need not be gone into here. Clashing vowels we will negotiate later in our voyage; for the present, we will leave on one side those places where only the supposition of hiatus would produce a rhythmic ending. (Where a rhythmic ending is produced only by elision, or crasis, of kinds not routine in prose, the passage is counted as nonrhythmic.) It does not especially matter how mute and liquid are treated, provided that we approach them in the same way across the texts that we consider. It is a tenable position that Attic in the Imperial period was valued as a spoken, not just a written, dialect, and that it is proper to apply the rules of shortening that we see in Attic speech of the fifth and fourth centuries BC; at any rate, they will be applied here. A few of the non-rhythmic Classical texts we will consider are admittedly in dialects other than Attic; but we are interested only in comparing with Appian the data a non-rhythmical text would produce, not in the rhythm these texts would have, if they had one, in their own dialect. Finally, there is the matter of Latin names. For some

\footnotetext{
${ }^{4}$ For the changes in Latin and Proto-Italic see A.L. Sihler, New Comparative Grammar of Greek and Latin (New York and Oxford, 1995), 68-70, 75-80, 83-5.
} 
names, scansion in Greek is obvious; but when it is not, closes that include them will be left aside. $^{5}$

\section{SENTENCES}

For the purposes of this article, I have scanned the whole of the Bella Ciuilia, a subset of Appian's larger creation. This is the most extended continuous part of his work. It is unlikely that one book of it would be rhythmic, one not; it is unlikely too that these books would be rhythmic

${ }^{5}$ Heibges (n. 1), 57-9 and Hunter (n. 1), 126 n. 1 adopt a different approach to mute and liquid; for our purposes it is best to be austere, and limit the possibilities for rhythmic endings. For reasons to be explained elsewhere, I have not gone so far as to suppose in Appian Attic lengthening before initial rho; equality has required the same treatment in the earlier texts which are used to provide comparative data. But the issue is of no significance for the argument: thus it affects none of the sentence-endings in B Civ. 5 or Lysias 1-7 and 9-10 (used in §II below). The

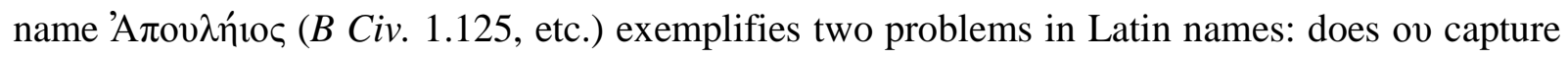
the quality of the Latin vowel but not form a long syllable? does - $\eta 1$ (despite editors' accentuation and non-subscript iota) capture Latin -ēi-, including the consonantal $i$ ? A metrical

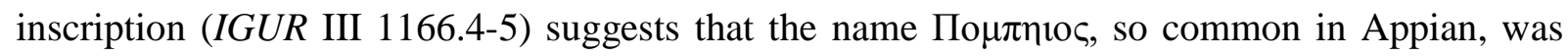
pronounced as three syllables. On Appian's knowledge of Latin, cf. É. Famerie, Le Latin et le grec d'Appien. Contribution à l'étude du lexique d'un historien grec de Rome (École Pratique des Hautes Études, IV ${ }^{e}$ Section, III Hautes études du monde gréco-romain 24, Geneva, 1998), 27-32. Note that Appian is probably not a Latin name: I. Hahn, 'Papyrologisches zum Namen Appians', Philologus 117 (1973), 97-101. 
and the rest of his Roman History not. I have read all the rest of his work with rhythm in mind, and have also taken random samples for numerical comparison; on this basis, it seems clear that what it is true of the Bella Ciuilia is true of the whole Roman History. The Civil Wars occupy 645 Teubner pages; over 20,000 endings to phrases or sentences have been examined.

It will eventually become apparent that rhythm in Appian informs the whole sentence, not just the end of it; but, since it is more difficult to determine where an internal phrase ends, the discussion will begin by looking at the ends of sentences. It will also at some points bring in half-sentences, that is, endings followed by a high point; there seems to be no difference as regards Appian's practice, but for the sake of perspicuity, attention will chiefly be concentrated on endings followed by a modern full stop. It will be borne in mind that no rhythmic prose is rhythmic throughout; to give a first rough example, the 108 sentences of Cicero's certainly rhythmic Pro Rabirio Perduellionis Reo, fragments excluded, give 95 rhythmic, 13 not $(88.0 \%$ and 12.0\%); 100 sentences of his certainly rhythmic Academica Priora (from 9 quibus de rebus to 32 relinquamus), in Plasberg's text, offer 93 rhythmic (with iudici at 19) and 7 non-rhythmic. If we took paragraph endings, a point where we might a priori especially expect a rhythmic close, in Thucydides Book 8 (OCT or Alberti) we find, documents and the very end aside, 41 closes that would be rhythmic if Thucydides had followed the Hellenistic system, 24 that would be non-rhythmic $(63.1 \%$ and $36.9 \%$ respectively of the total rhythmic + non-rhythmic). (One other close would need hiatus to be rhythmic and is left out of account; 3 of the non-rhythmic endings would become rhythmic with elision, in one case with elision of $\tau \alpha \hat{v} \tau \alpha$, elided 5 times, it seems, in Thucydides' MSS.)

In Book 1 of Appian, paragraph endings in Mendelssohn-Viereck's edition are 70 rhythmic, 11 non-rhythmic ( $86.4 \%$ and $13.6 \%$ of rhythmic + non-rhythmic). (4 further paragraph 
endings would be rhythmic but would require hiatus and are omitted; one non-rhythmic paragraph ending (1.31) would be rhythmic if we elided $\alpha v \tau i$, as apparently 14 times in Appian's MSS, one (393) if we elided $\tau \alpha \hat{v} \tau \alpha$, as apparently 63 times in Appian's MSS.) In Book 1, if we exclude endings which require hiatus to be rhythmic, 606 sentences end rhythmically, 81 not, that is $88.2 \%$ rhythmic, $11.8 \%$ non-rhythmic; the sentences of Book 2 give 694 rhythmic, 83 non-rhythmic, that is $89.3 \%$ and $10.7 \%$. In Book 3, the sentences are 464 rhythmic, 63 nonrhythmic, that is $88.0 \%$ and $12.0 \%$. (1 of the non-rhythmic endings in Book 1, 4 in Book 2, and 1 in Book 3 would become rhythmic with hiatus but the hiatus would need to replace a manuscript elision; they are left as non-rhythmic, not excluded.) We could also look in Book 3 at colons as well as full points; together they produce 631 rhythmic endings, 79 non-rhythmic, that is $88.9 \%$ and $11.1 \%$. The same two exercises for Books 4 and 5 yield: Book 4: rhythmic sentence-endings 575, non-rhythmic 99 (85.3\% and 14.7\%); Book 5: rhythmic sentence-endings 627, nonrhythmic 88 (87.7\% and 12.3\%); Book 4: endings at colons and full points rhythmic 786, nonrhythmic $136(85.2 \%, 14.8 \%)$; Book 5: endings at colons and full points 816 rhythmic, 120 nonrhythmic $(87.2 \% \text { and } 12.8 \%)^{6}$

\footnotetext{
${ }^{6}$ Note that Klock (n. 1), 230 treats high point before direct speech as weak punctuation. To avoid suspicion of choice or change on rhythmical grounds, Mendelssohn-Viereck's text of B Civ. has been followed throughout (but not always in punctuation). Problems of text rarely affect rhythm

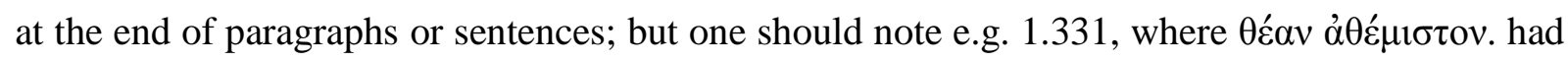

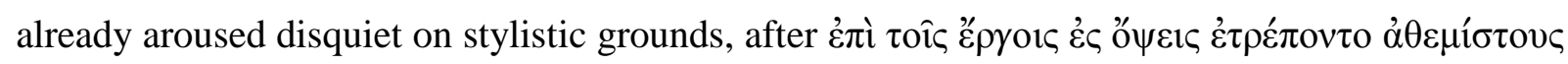

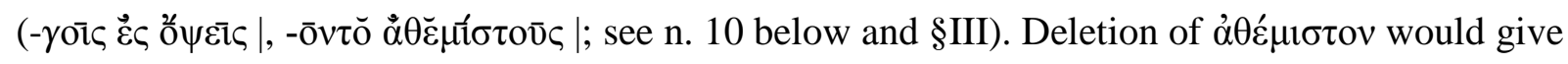
a rhythmic ending. If Appian is indeed rhythmic, textual criticism will need to bear it in mind. Thus P. Goukowsky, 'Sur les funérailles de Pompée', in Cl. Brixhe (ed.), Hellènika symmikta.
} 
We should try to form some kind of comparison between these figures and the figures for an author unlikely to use the Hellenistic system of rhythm. We may first take the sentenceendings in Book 5 and compare them with the sentence-endings in Lysias speeches 1-7 and 9-10; these are 429 rhythmic, 289 non-rhythmic $(59.7 \%$ and $40.3 \%$; the same exclusion for hiatus as with Appian). To get the total exactly the same as in Appian Book 5, we may leave off the last 3 sentences of Lysias and so get 427 and 288 (same percentages). We could now employ a chisquared test, to see how likely it is that the difference between the figures is due to chance. It would be prudent to use the method which will produce a higher probability of chance: that is, we are not yet supposing we can predict an average result, but are merely comparing two sets of data. The procedure is to calculate the sum of the two values of

$(n 1-n 2)^{2} /(n 1+n 2)$

where $n 1$ and $n 2$ are the numbers observed in a given category in the two sets of data; in our case the categories will be first rhythmic endings, and then unrhythmic endings, $n 1$ in Appian and $n 2$ in Lysias. We square the difference between 627 and 427 (rhythmic endings) and divide it by the

Histoire, linguistique, épigraphie 2 (Paris, 1995), 55-61, at 58-9 brings forward for 2.361 the

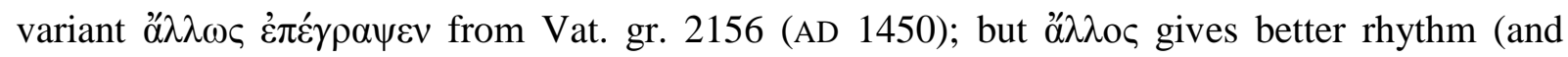
sense), on my view of mute and liquid. In considering the authorship of the new fragment Goukowsky ascribes to Appian, one would have to see if it looked rhythmic (it does) ('Trois nouveaux extraits d'Appien', ibid. 63-70, at 65-8; cf. Hisp. 8). (More on the contents of the MS: M.L. Amerio, 'Ancora sui nuovi frammenti di Appiano', Invigilata Lucernis 21 [1999], 35-42.) 
sum of 627 and 427, and so with the difference between 88 and 288 (unrhythmic endings); we then add the two figures together. So $\chi^{2}=(627-427)^{2} /(627+427)+(88-288)^{2} /(88+288)$ $=144.33$

There is only one degree of freedom (our four figures in a table would give 2 rows and 2 columns; if we subtract 1 from each 2 and multiply, we obtain 1 ). With $\chi^{2}=144.33$ we would pass far beyond the usual tables for probability, and arrive at a probability of purely random difference so small-with such a string of noughts after the decimal point-that it can be regarded as equivalent to zero. The same would apply if we took from Appian a sample with a lower proportion of rhythmic endings; so the sentences of Book 4 (575 rhythmic, 99 nonrhythmic; $85.3 \%$ and $14.7 \%$ ) may be set against the first 674 sentences from the sample in Lysias (400 rhythmic, 274 non-rhythmic; 59.3\% and 40.7\%). $\chi^{2}=113.51$. For the sake of comparison, if $\chi^{2}$ were 10.83 , the probability would be 0.001 ( 1 in 1,000$)$, if $15.14,0.0001(1$ in 10,000$){ }^{7}$

This seems encouraging. The problem with our proceedings so far is that the sentences form a single stretch of text or a set of texts (some of Lysias' speeches); they are either consecutive (Appian) or usually so (Lysias). Yet the assumption of such a test is that the instances are independent; the close cohesion of the sentences conflicts with this assumption. The result of the calculation is still so remarkable that it looks likely that the two sets of data are different kinds of thing; but we must try some further tests to give our impression more solidity.

\footnotetext{
${ }^{7}$ For a table see M.L. Samuels and J.A. Witmer, Statistics for the Life Sciences (Upper Saddle River, NJ, and London, 2003 3 ), 686 (appendix of tables omitted from fourth edition). For the type of $\chi^{2}$ test which compares two unknown distributions to ascertain if they are different, see W.H. Press, S.A. Teukolsky, W.T. Vetterling, B.P. Flannery, Numerical Recipes in C: The Art of Scientific Computing (Cambridge, 1992²), 620-3, esp. 622.
} 
First we may try a smaller sample of randomly chosen sentences within the two bodies of data used in our original test. The smallness of the sample already means that the result will be less striking. 100 sentences were chosen randomly from the same portion of Lysias and from Appian, Bella Ciuilia 5; any that were unusable for the familiar reasons (hiatus and Latin names) were replaced by other randomly chosen sentences. The result was: Appian: rhythmic 82, nonrhythmic 18; Lysias: rhythmic 56, non-rhythmic 44 . Here the same $\chi^{2}$ test produced 15.80 ; the probability of chance is, as we have seen, $<0.0001$ (less than 1 in 10,000). In a second and larger supplementary test, 20 sentences were chosen at random from 20 authors unlikely to use the Hellenistic system of rhythm; these were compared with 400 sentences chosen at random from the whole Bella Ciuilia. (We are not yet in a position to provide a matching twenty authors of rhythmic prose, since we are only in the course of showing that even one particular Imperial Greek author wrote rhythmically.) Again in both cases unusable sentences were replaced with usable ones randomly selected. The 400 sentences of Appian gave 328 rhythmic closes, 72 nonrhythmic ( $82 \%$ and $18 \%)$. The twenty authors produced 249 rhythmic closes, 151 non-rhythmic closes $(62.25 \%$ and $37.75 \%) .(328-249)^{2} /(328+249)+(72-151)^{2} /(72+151)$ gives $\chi^{2}$ as 38.80283825. This figure again is too high for the tables, and results in a probability of chance that may be regarded as in practice equivalent to zero. We already have, then, a decisive proof. ${ }^{8}$

These were the specific numbers for rhythmic sentences, which show a range limited to between 9 and 14 out of 20: Heraclitus (already fragmented; of course non-consecutive sentences only) 14, Herodotus 9, Gorgias 13, Antiphon 13, Andocides (1-3) 12, Thucydides 12, Hippocratic corpus (vols. 1-2 Kühlewein) 13, Lysias 14, Plato (first 3 volumes of OCT) 14,

\footnotetext{
${ }^{8}$ Out of the non-rhythmic endings in the 400 sentences of Appian, 60 were forms of - - -, 12 were forms of $-\cdots-\cdots$; of those in the twenty authors, the figures were 138 and 13.
} 
Xenophon 13, Isaeus 11, Aeneas Tacticus 14, Demosthenes 11, Aeschines 14, Apollodorus ([Demosthenes] 46, 49, 50, 52, 53, and 59) 9, Hyperides 13, Dinarchus 13, Lycurgus 13, Aristotle 11, Theophrastus (Historia Plantarum and De Causis Plantarum) 13.9

\section{HIATUS}

Two further strong arguments may be brought in, partly to add still more assurance, but also to show the practical effect of the rhythmic system, and to take us deeper into the nature of Appian's rhythmic prose. First, hiatus.

Cicero is well known to avoid, almost entirely, the use of atque followed by a consonant except in rhythmic closes, though these sometimes extend further back into the sentence than in the standard forms of them adopted here. This clear connection between an unusual feature and rhythm helps to confirm that Cicero is writing rhythmically. Many Greek authors of the Imperial period are well known to avoid hiatus, though not entirely. Suppose that Appian employs hiatus, save for the commonest words, preponderantly at closes that would be rhythmic; that would show a strong connection between the two phenomena, and help to confirm that rhythm is real,

\footnotetext{
${ }^{9}$ Pherecydes of Athens was originally one of the twenty, but later banished, since it was feared so many dactylic names would produce an abnormal specimen of non-rhythmic prose. Lycurgus took his place.
} 
that he is writing rhythmically. It would also provide anticipatory confirmation of a point we will come to presently, that rhythm is not confined to the end of sentences or half-sentences. ${ }^{10}$

We would do best to exclude from consideration (a) places where there is a significant possibility that the first of the two vowels could be elided (or the second prodelided, or both merged in crasis): these are not adequately clear cases of hiatus. We would also do best to exclude (b) very common words, notably kaí and ó (any part), where hiatus seems not greatly to concern authors of the period: here the presence of hiatus is not striking, and so does not provide a salient departure from a usual avoidance. The two classes (a) and (b) come together, since MSS and papyri seem to indicate that in Greek prose it is usually common words, not words in general, which are liable to elision. It would be perilous to use the authority of MSS and papyri to assert that there is elision at any particular point; but the general diffusion of this approach in them is a strong reason for caution in supposing hiatus with such words. After all, literary papyri on the whole come from Egypt, and the greatest number from the second century AD: precisely the milieu of Appian. The presence of Appian himself on papyri is exiguous; but we may take an example from a recently published second-century papyrus of Plutarch, close to the author's

10 See R.G.M. Nisbet, 'Cola and clausulae in Cicero's speeches' [1990], Collected Papers on Latin Literature (ed. S.J. Harrison; Oxford, 1995), 312-24, at 319-22 for atque and at 316-18 for the occurrence of hiatus after clausulae; Hutchinson (n. 3) at 486-90 and 496 for atque. Hiatus in Appian is discussed by A. Zerdik, Quaestiones Appianeae (Diss. Kiel, 1886), 49-82: a useful collection of material, though the significance of rhythm is not glimpsed (partly a matter of date, cf. F. Novotný, État actuel des études sur le rythme de la prose latine [Eos Suppl. 5, Lwów, 1929], 2-33 for history of study); contrast Heibges (n. 1), 54-6, though he does not distinguish between common words and others. 
lifetime. It displays $\alpha \lambda \lambda \omega \sigma \pi \varepsilon \rho$ at Plut. De prof. virt. 75C (P.Oxy. LXXVIII 5153 col. ii 4); the MSS, according to Gärtner's edition of 1993 , have $\alpha^{\prime} \lambda \lambda^{\prime} \dddot{\omega} \sigma \pi \varepsilon \rho . \dot{\alpha}^{\prime} \lambda \lambda^{\prime}$ is far commoner than $\dot{\alpha} \lambda \lambda \alpha^{\prime}$ followed by vowel as the two forms are reported for the MSS of Appian (290 to 47; for the Civil Wars, B is Mendelssohn-Viereck's principal guide). There is at the least a considerable possibility that Appian most often wished the word to be elided. With other common words, the MSS of Appian sometimes elide, sometimes not: thus 2480 instances of $\delta^{\prime}$, as against 1688 of $\delta \varepsilon ́$ + vowel. In general, elision must be considered a serious possibility for such words, whether universally or sporadically. ${ }^{11}$

Many of the words where elision, crasis, etc., occur often or from time to time in the MSS of Appian and other authors: $\delta \dot{\varepsilon}, \tau \varepsilon$ (much more rarely elided in Appian than $\delta \dot{\varepsilon}$ ), $\dot{\alpha} \lambda \lambda \alpha_{\alpha}$,

11 Once the existence of rhythm is established, the most plausible hypothesis will be that with these words elision sometimes operates, sometimes not; the reader's rhythmic sense could have

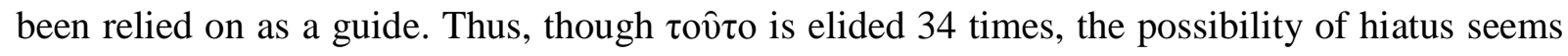

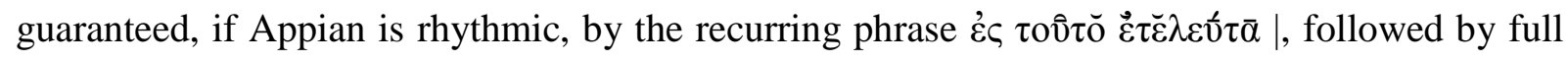
stop Sic. fr. 2.5, Mac. fr. 9.4, by high point B Civ. 5.155, by comma at Hisp. 322, B Civ. 5.352. (Rhythmic closes, potential or actual, are marked by | for their end; | is used for the first close when two overlap [pp. [27-8] below]. When | appears at the beginning of a quotation, it indicates that the words begin directly after a rhythmic close.) Note that P. Dur. 2 fr. A does not support, as T.F. Brunner thought, the manuscript $\sigma \tau \rho \alpha \tau \iota \grave{\alpha} \nu \delta \dot{\varepsilon} \alpha \dot{\alpha} \varepsilon \dot{\rho} \rho \alpha \varsigma$ at $B C i v .2 .27$, where rhythm would favour elision; see C.B. Welles, 'Fragments of Herodotus and Appian from Dura', TAPhA 70 (1939), 203-312; T.F. Brunner, 'Two papyri of Appian from Dura-Europus', GRBS (1984), 25, 171-5; R.G. Babcock and W.A. Johnson, 'The Appian papyrus from Dura-Europus (P.Dura 2)', Bulletin of the American Society of Papyrologists 31 (1994), 85-8. 


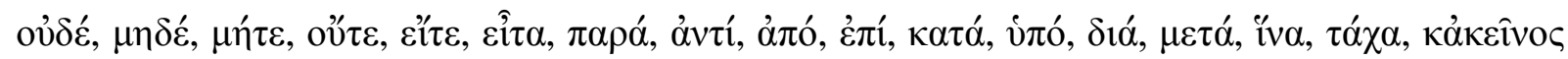

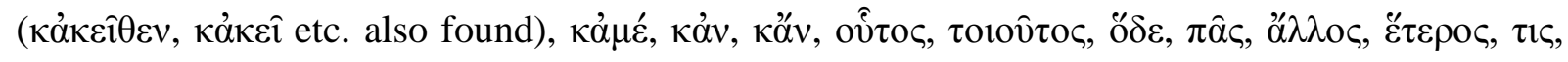

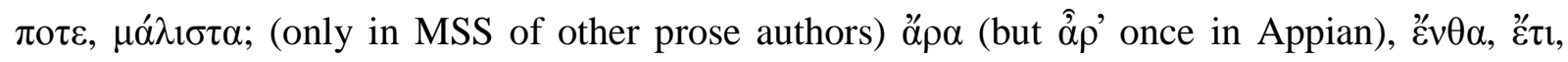

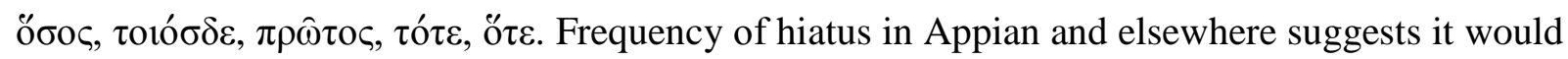
also be reasonable to exclude hiatus after the following: $\dddot{\eta}, \pi \alpha ́ v v, \pi \varepsilon \rho i ́$, possessive adjectives ( $\tau$ ô

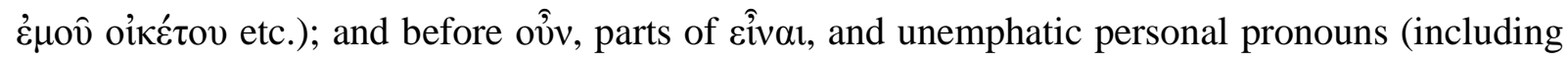

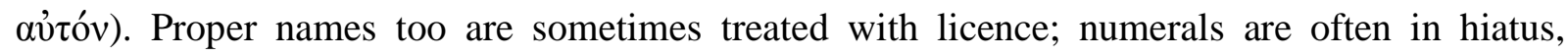
especially the lower ones. We should further omit places where the hiatus is accompanied by punctuation, since pause in the sentence would sufficiently justify it; the only exceptions are where the commas of editors seem purely syntactic and pause not inevitable. ${ }^{12}$

It may be most enlightening to take a limited portion of text, and consider the occurrences of hiatus in some detail. (Italics are used for the hiatus which concerns us in each example.) These are the majority of instances from Book 5.1-200 before colon or full point where elision is unlikely and hiatus - in most cases only hiatus — would produce a rhythmic ending: 1 (first

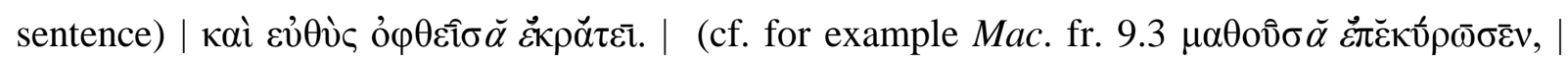

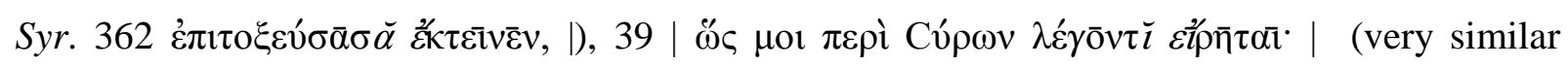

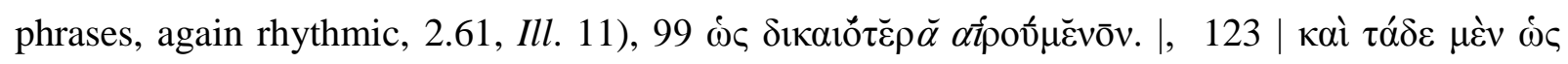

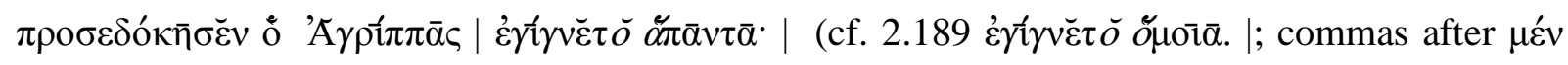

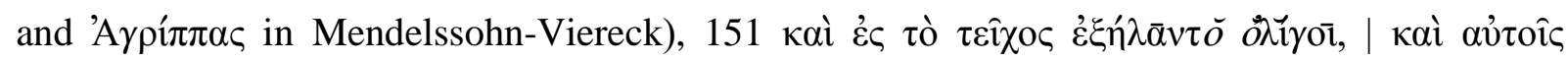

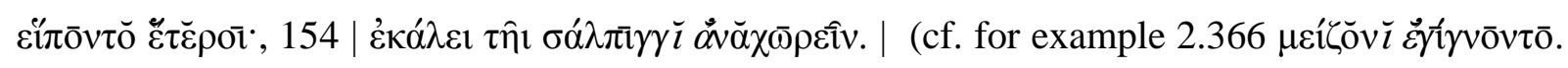

\footnotetext{
12 After Appian's rhythmic status is accepted, it will become legitimate to look again at hiatus with common words; it will be clear that even here a great many instances form part of rhythmic phrases.
} 


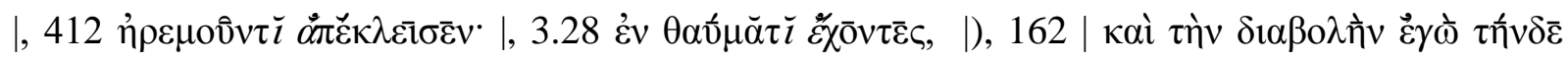

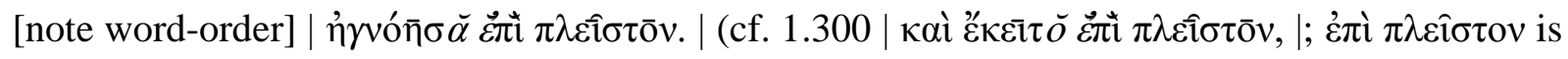
often the last part of a rhythmic ending without hiatus, cf. for example (with full stop or colon to

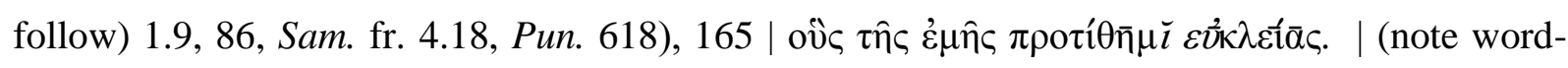

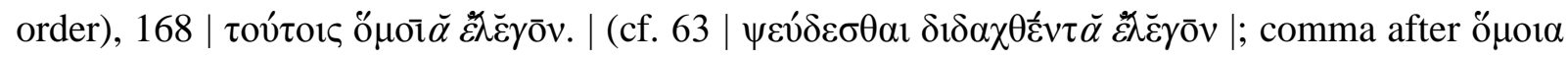
in Mendelssohn-Viereck).

Within the sentence or part-sentence, elision is unlikely and hiatus would produce a

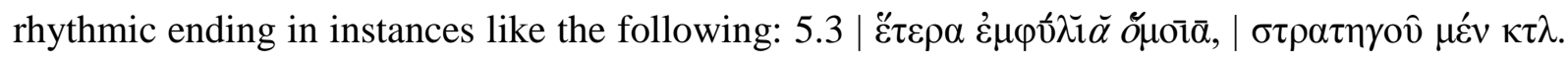

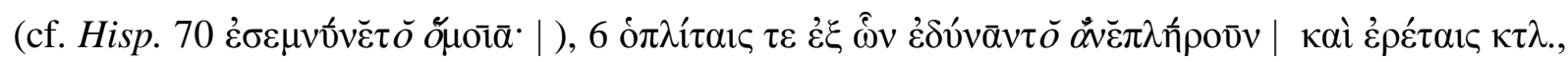

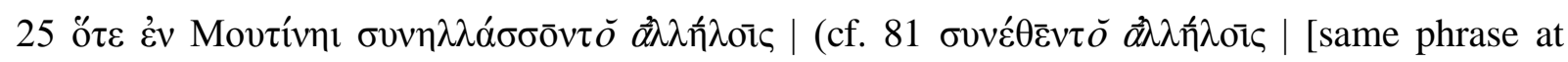

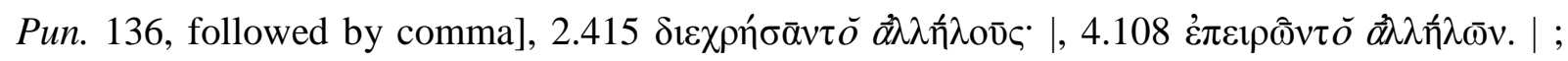

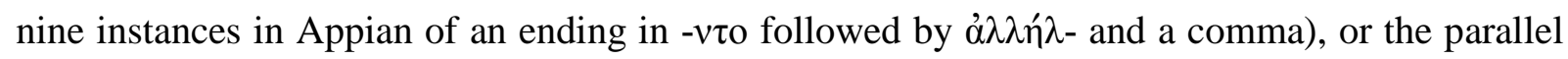

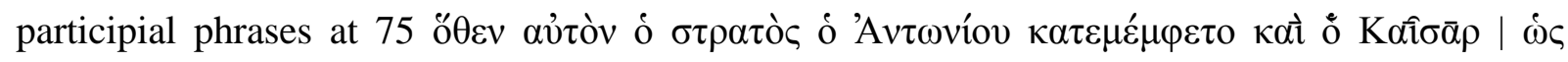

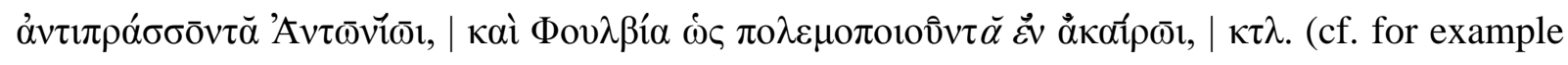

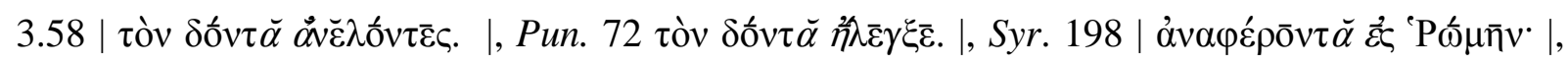

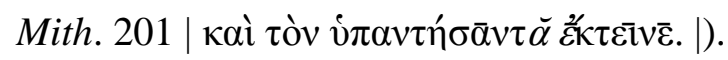

It already looks as if there is a relation between hiatus and rhythm. Now we need to take a more general look at hiatus within the portion of text 5.1-200. The broad picture, which applies to the Civil Wars as a whole, is that general rhythmical principle allows hiatus, like brevis in longo, after a rhythmic close, so at the end of a phrase and in 'metrical' pause; in these cases the first element in the hiatus may be a short vowel or a long vowel or a diphthong. Hiatus is also permitted where a phrase ends unrhythmically, as a sentence can; the same point about the first element applies. Within a phrase, if the common words above are excluded, hiatus is at the least 
rare except as part of a rhythmic close; in hiatus within a rhythmic close, the first element is normally a short vowel. This picture suggests a special connection between hiatus and rhythm. It is arguable that there are no actual exceptions in this portion; if there are a few exceptions, the preponderance that remains suffices to establish a significant pattern, and thus the presence of the rhythmic system in the text. It would be reasonable to maintain that in two apparent exceptions we are again dealing with very common words or word-groups after which hiatus

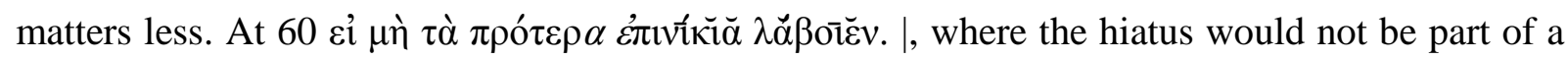

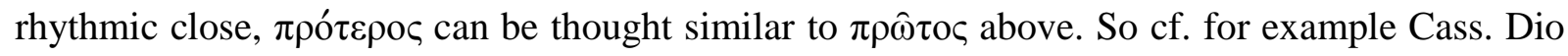

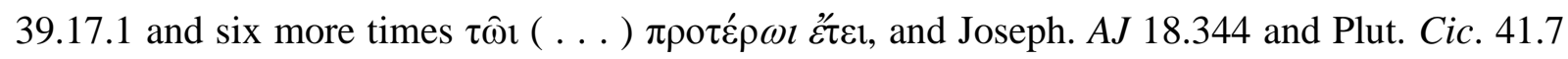

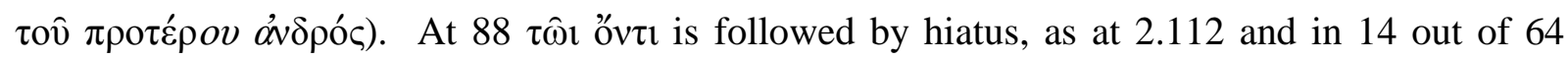
occurrences of the phrase in Dio of Prusa (excluding from the 64 two places where the phrase is

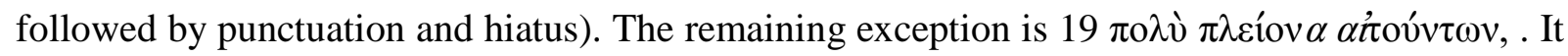

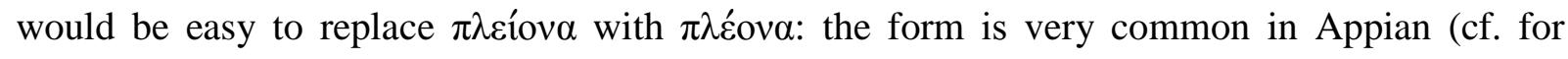
example 5.51, and note the similarly tempting close of a sentence in the MS at Pun. $490 \pi \mathrm{o} \lambda \dot{v}$

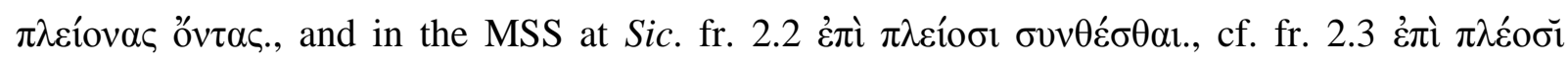
$\sigma \breve{v} v \breve{\varepsilon} \theta \bar{\varepsilon} v \tau \overline{0} . \mid){ }^{13}$

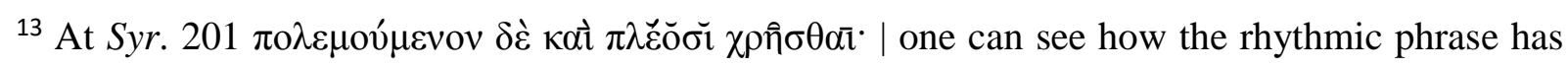
been added to Polyb. 21.43.13, cf. K. Brodersen, Appians Antiochike (Syriake 1,1-44,232). Text und Kommentar nebst einem Anhang: Plethons Syriake-Exzerpt (Münchener Arbeiten zur Alten Geschichte 3 [Munich, 1991], 203); note the alterations of Polybius in a rhythmic direction e.g.

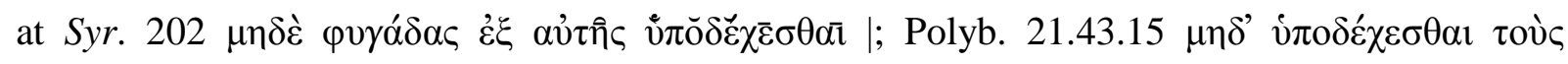

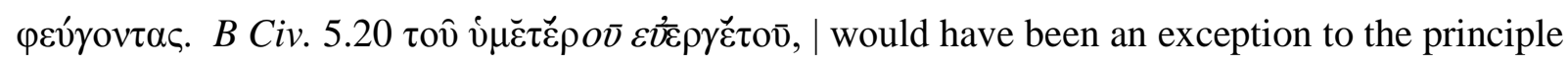
on the short first element if we had not excluded possessive adjectives; but cf. e.g. Philo, Leg. 
We have not yet discussed the nature of phrases; 'phrase' is only a shorthand, since a sizable single word can form a separate entity for these purposes, and a brief beginning to a sentence or part of it can be followed by a break and the main start. In all the instances of hiatus from $B$ Civ. 5.1-200 which could be inside phrases but not as part of a rhythmic close, actually the word or group of words, or those following, or both, are marked out by emphasis in the meaning of the sentence, and thus detachment and the end of a phrase are apt. Here, then, the phrases close unrhythmically. Particles, word-order, or a long first element in the hiatus provide

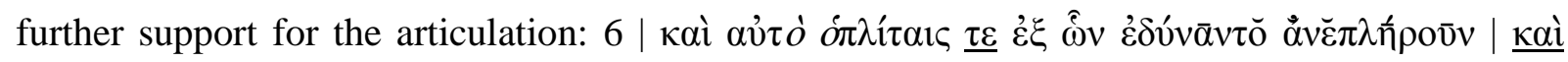

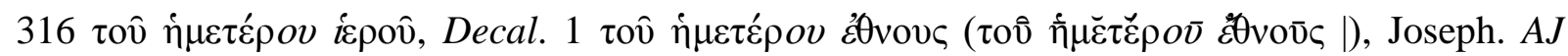

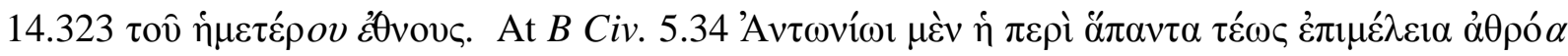

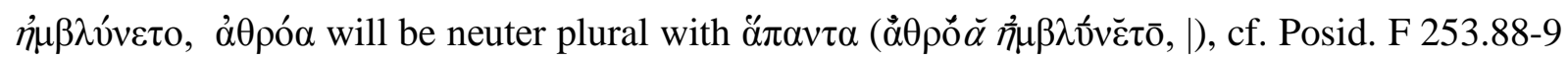
Edelstein-Kidd, Philo, Abr. 199, Luc. Tyr. 18. To make sure that no instances of hiatus in 5.1200 were missed, $-\alpha \alpha-,-\alpha \varepsilon-$, etc., were searched for by computer. In the Civil Wars generally, there are exceptions to the picture given above, but they are infrequent. A particularly intractable

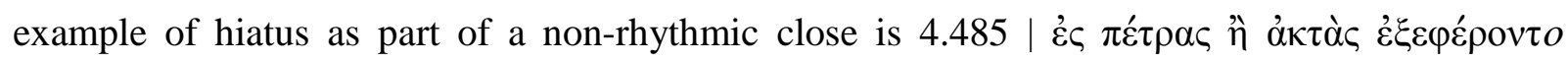

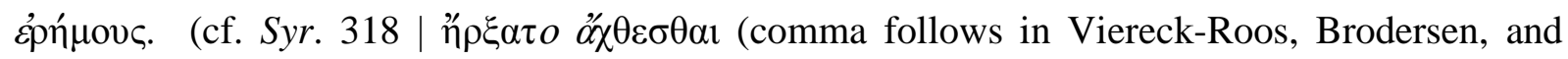

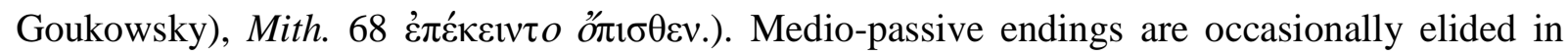

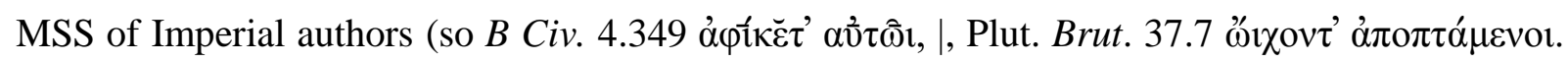

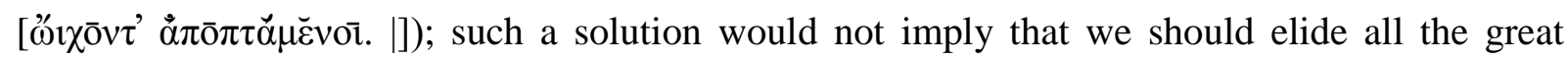
number of Appian's medio-passive endings in hiatus (it would become an inexplicable coincidence that they occur mostly in rhythmic phrases). For diphthongs (not simple long

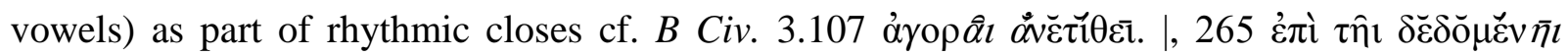

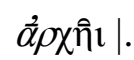




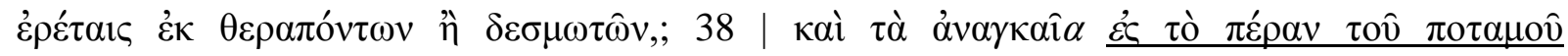

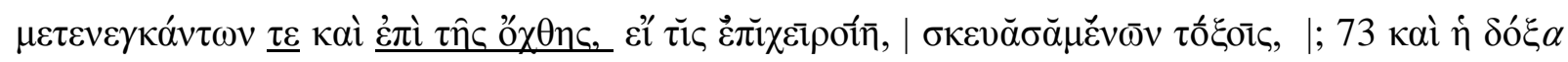

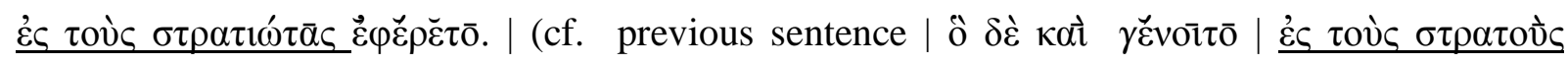

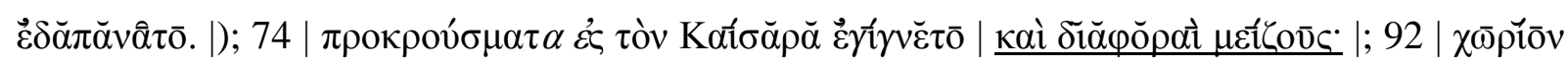

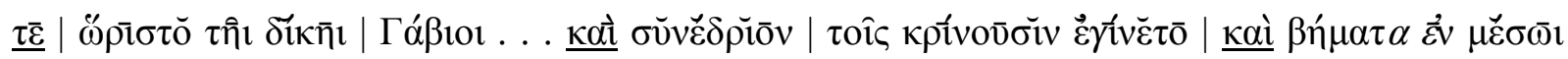

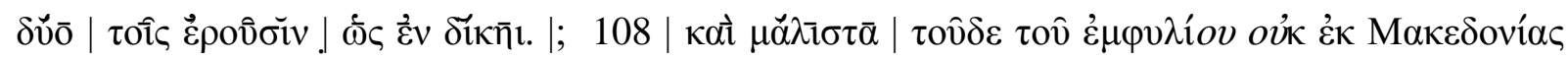

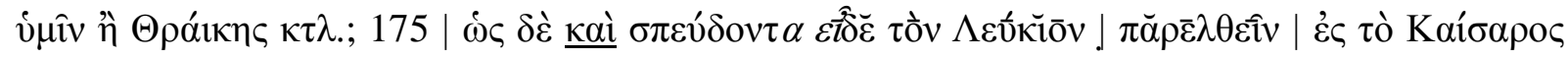

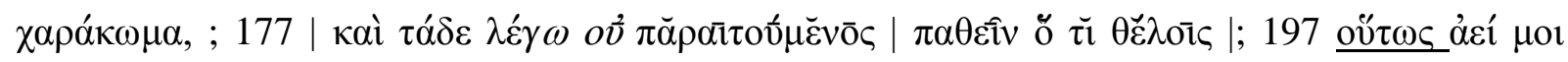
$\pi \rho \circ \sigma \varepsilon v \operatorname{vi}_{\varepsilon \chi} \theta \varepsilon \underline{\omega \varepsilon} \kappa \tau \lambda .{ }^{14}$

Similar principles apply to the demarcation of phrases that are rhythmic, when there is no punctuation; we are thus not trapped in a circular dependence on rhythm alone. Here are some examples, either for hiatus which forms part of a rhythmic close or for hiatus the first element of which occurs at the end of a rhythmic close. It will be noted that only in the latter type can the

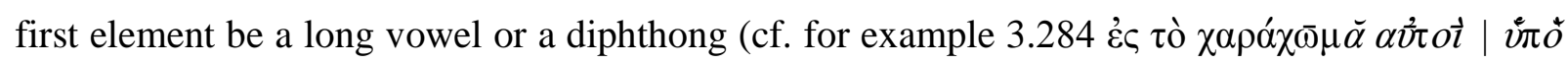

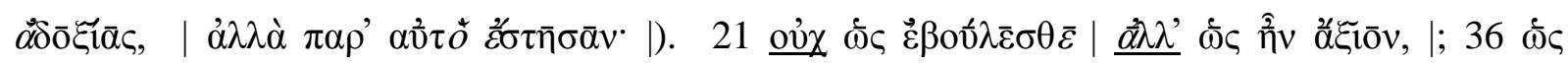

${ }^{14}$ Ed. Fraenkel, 'Kolon und Satz, II' [1933], Kleine Beiträge zur klassischen Philologie (2 vols., Rome, 1964), 2.93-139, at 117 n. 1 and 135 views as a 'Kurzkolon' even an opening particle when followed by another word followed by ớv; in 'Nachträge zu "Kolon und Satz, II"”, ibid. 131-9, at 138 n. 2 he inclines to the promising designation 'Auftakt'. At the other end of the sentence or part of it, apparent hiatus within an unrhythmic phrase can be actually at the end of a rhythmic phrase, followed by a short unrhythmic close; cf. e.g., outside the Civil Wars, Mac. fr.

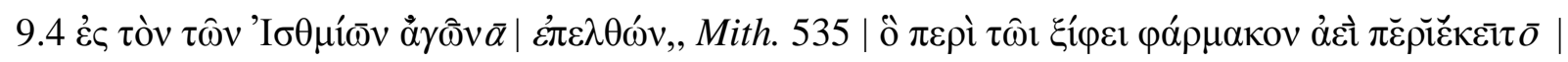

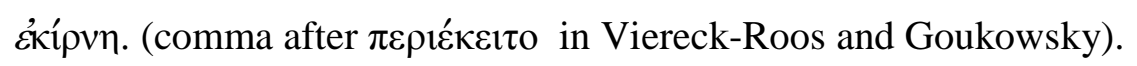




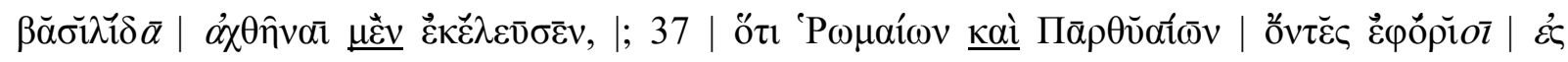

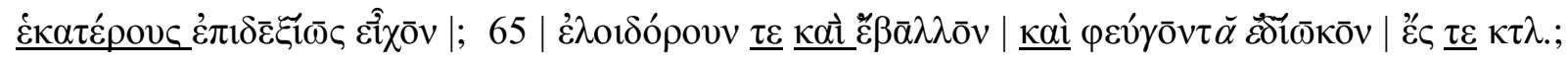

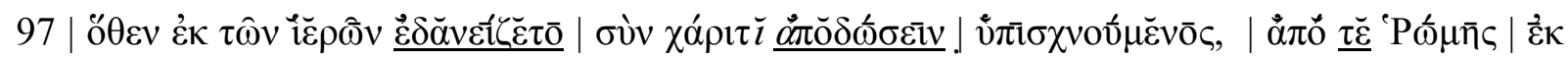

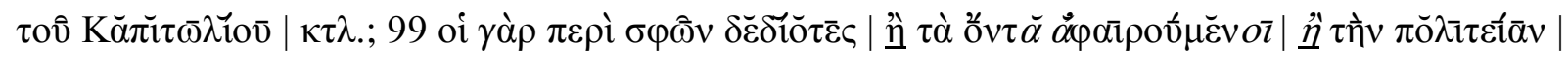

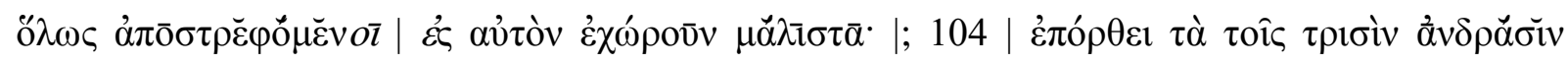

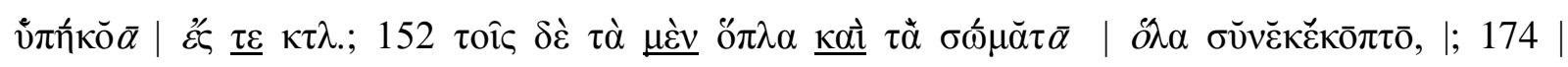

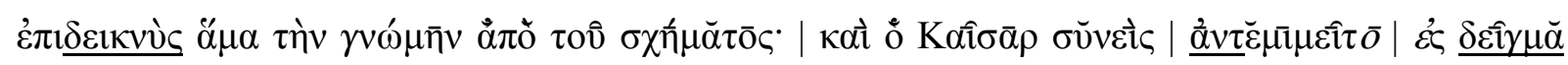

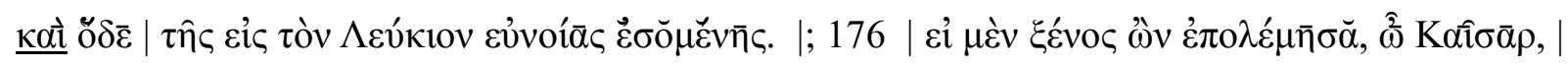

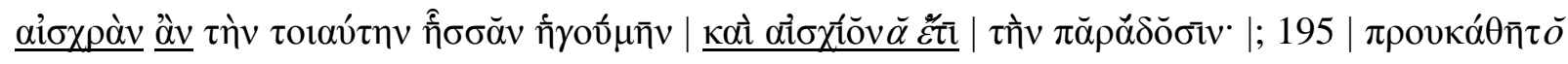

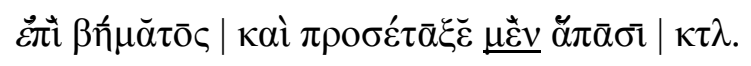

It is clear enough that the use of hiatus follows a system. This system is bound up with rhythm, and hence the existence of this system helps to confirm the existence of rhythm. In other words, the lesser system implies the larger one.

\section{PHRASES}

The second confirmatory argument is for the reader particularly strong. Closes which appear rhythmic occur in Appian not just at the end of sentences or half-sentences but throughout the sentence. It would be rare to find 15 consecutive words, as words are conventionally counted, where there was not an apparent rhythmic close (a few seeming exceptions, like 1.451 from oi

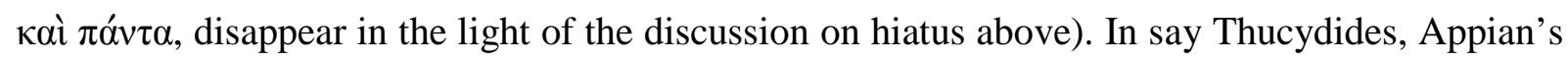
chief model, it is not rare to find a stretch of 15 words with no close that would be rhythmic

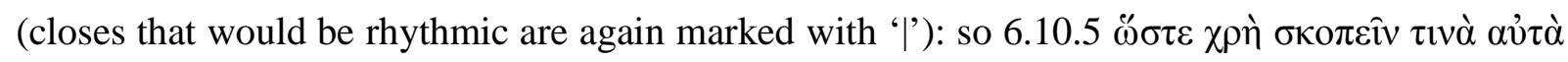




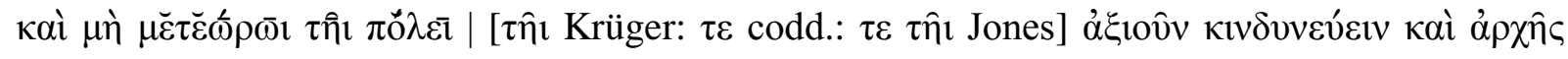

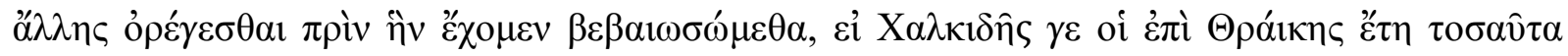

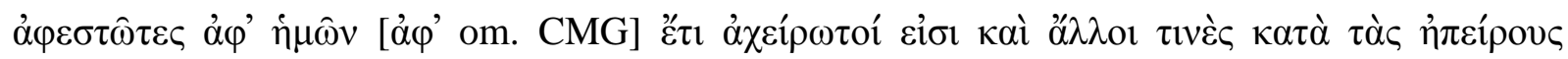

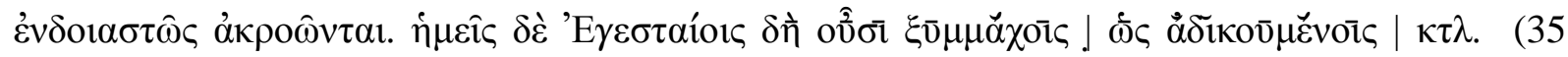

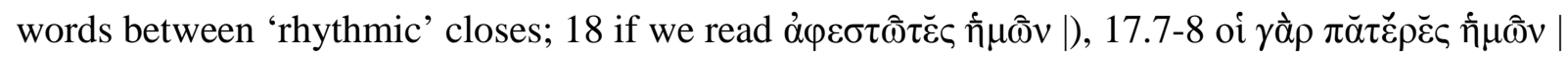

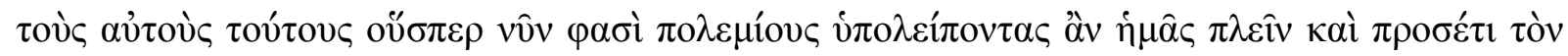

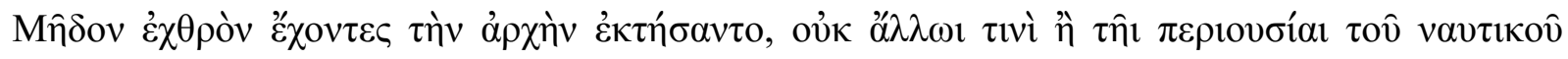

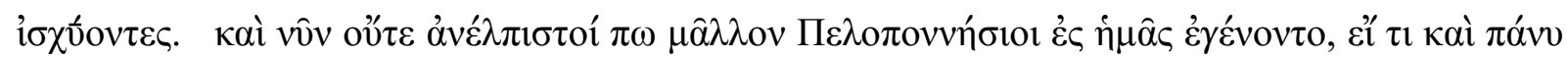

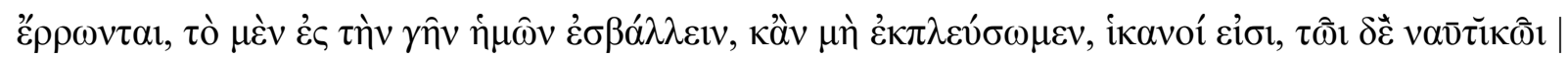

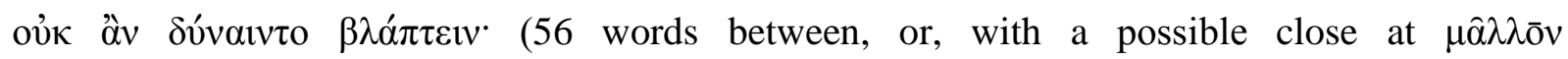

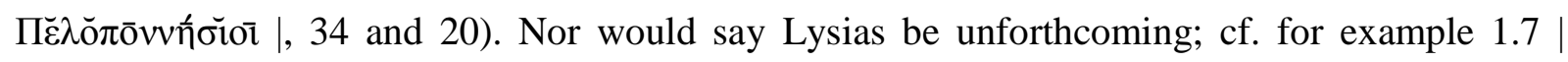

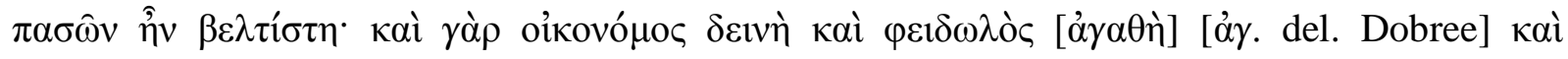

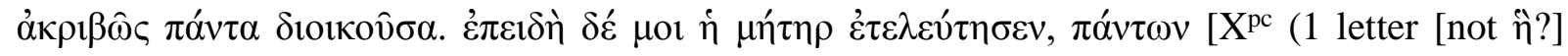

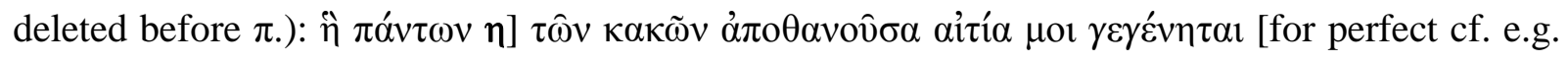

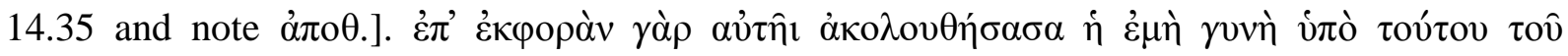

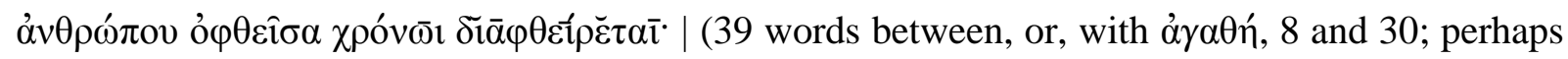

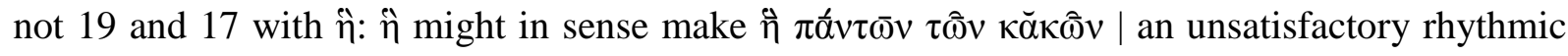
phrase).

If we take a short passage at random from Thucydides 7 (38.2), and treat it as if rhythmic,

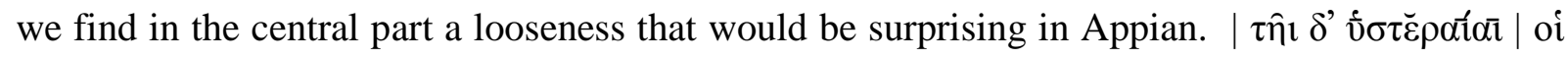

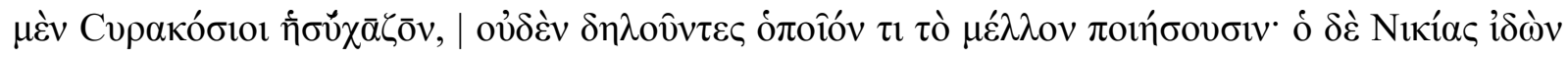

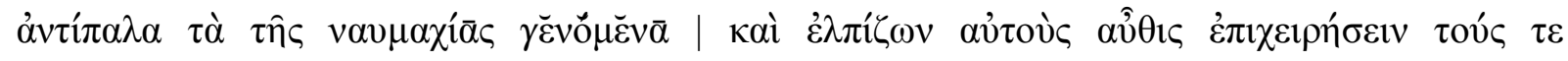

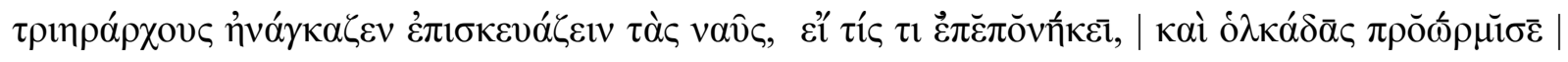

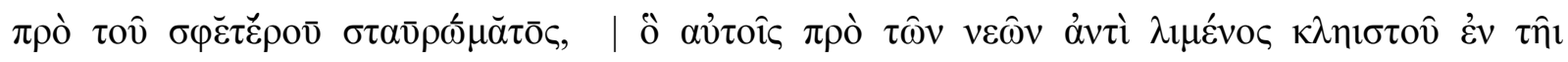




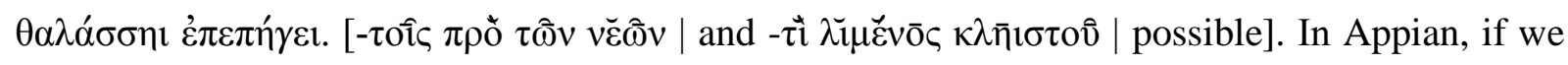
ignore the existence of phrases which are self-contained but non-rhythmic, that is if we treat such phrases, except when full stop or colon follows, as part of the next phrase with a rhythmic close, then phrases containing rhythmic closes seem to have an average of six or seven words. (This average treats overlapping rhythmic closes [see pp. [27-8] below] as two phrases.) If we take the most famously affecting passage in Thucydides Book 7-and in Appian rhythmic density is notably found at intense moments-we find sequences of at least 31 and 21 words between

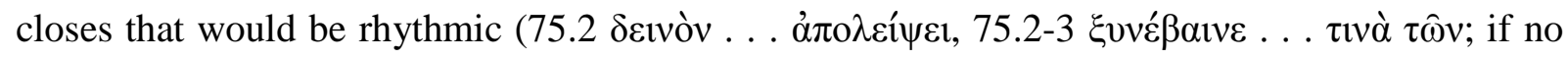

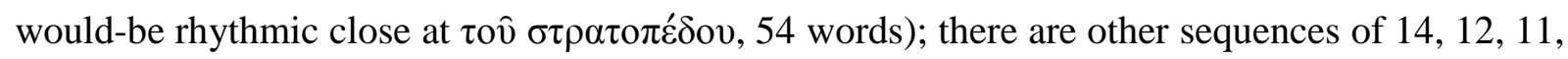

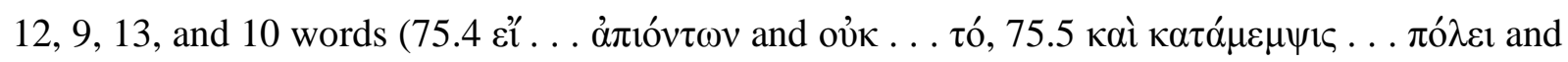

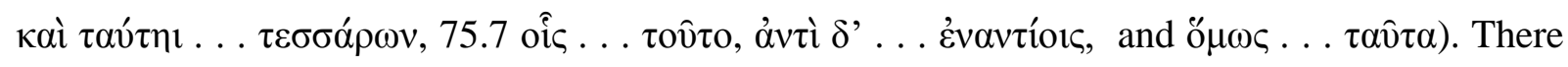
is no remotely similar passage in the Civil Wars.

So far, the assumptions made on where a rhythmic close is to be found have not impeded the argument: less generosity on both sides of the equation would still leave a substantial gap between Appian and non-rhythmic prose. But working our assumptions out more explicitly will take us further into the rhythmic quality of Appian's writing. Here it will be necessary to show what a reading of the prose as rhythmic would look like, and so to posit such reading as a hypothesis; the neatness with which it fits the text will then confirm the hypothesis. But the emphasis of the discussion will not be solely on further establishing Appian's rhythmic status: the literary roles of rhythm will also start to emerge.

A good place to begin, as was glimpsed in the previous section, is particles. Some particles tend to indicate that the phrase they belong in is substantial enough to be considered rhythmic-provided, of course, that it is long enough to contain a rhythmic close. The same 
applies to what precedes a phrase which is marked as beginning by a particle, whether prepositive or post-positive; so does the proviso on length. Part of what the proviso ultimately requires is that the reader (or listener) should be capable of noticing rhythmic phrases and should identify them as such if they emerge. That seems a reasonable model to work with, and will be reinforced when we come to overlapping rhythms.

Some examples, starting with two to illustrate what the reader does: $2.270 \ldots \tau$ ò $\delta \grave{\varepsilon}$

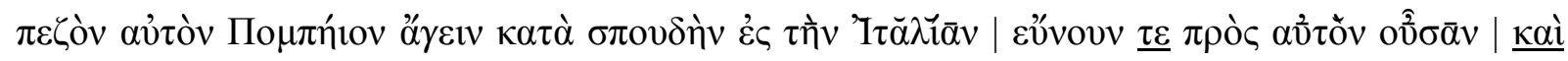

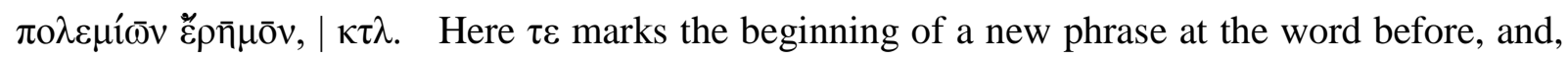
because that phrase is long enough for a rhythmic close, кaí is seen to mark a new phrase too; these two phrases with rhythmic close balance each other. By contrast, in what follows,

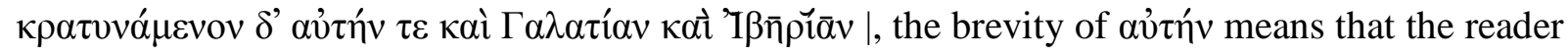
does not attempt to make $\alpha$ $\tau$ ท́ $\tau \varepsilon$ a rhythmic phrase on its own, but rather part of the single

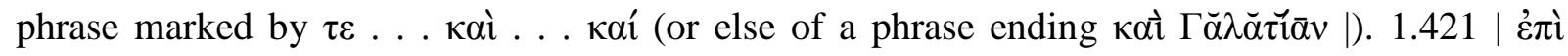

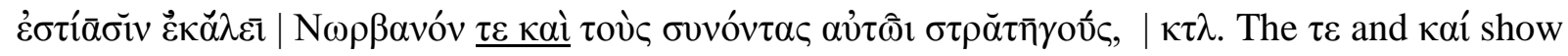

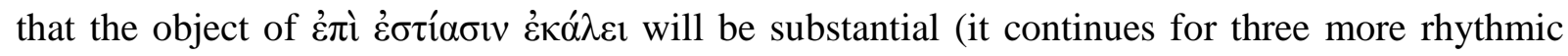
phrases); the reader can then take that initial verbal phrase as a self-contained and rhythmic unit. Its potential rhythmic close had already opened that as an option.

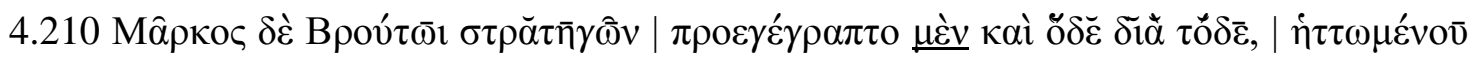

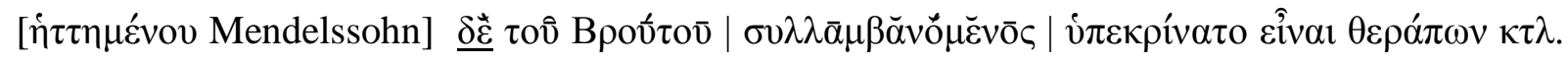

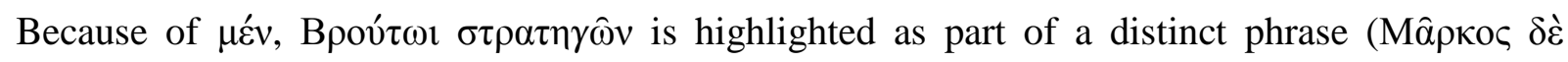

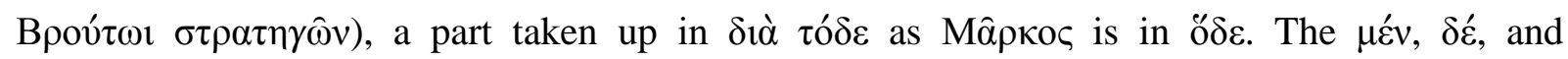
pluperfect set up connections between the third and fourth rhythmic phrases and the first and 
second, and $\sigma \tau \rho \alpha \tau \eta \gamma \hat{\omega} v$ contrasts with $\theta \varepsilon \rho \alpha ́ \pi \omega v$ (cf. 185 (disguise as slave); 194 (disguise as praetor)). The rhythm thus helps to articulate point for the phrases within the sentence. ${ }^{15}$

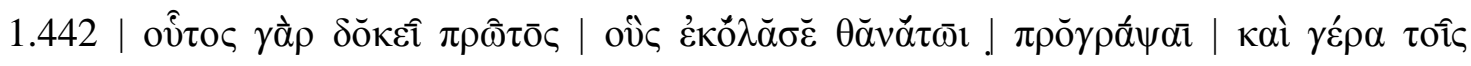

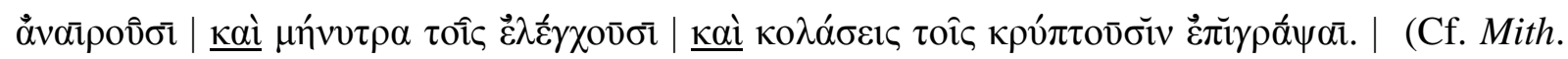

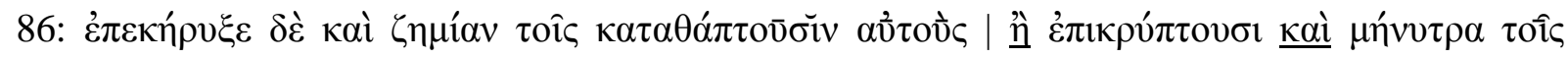

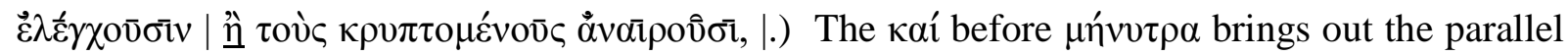
between the phrase with rhythmic close that it introduces and the phrase with rhythmic close that

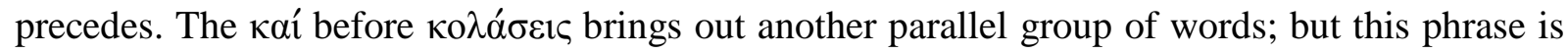

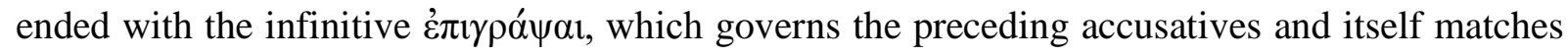
the infinitive $\pi \rho \gamma_{\rho} \alpha \dot{\psi} \psi \alpha 1$, which rhythmically ended the first half of the sentence. ${ }^{16}$

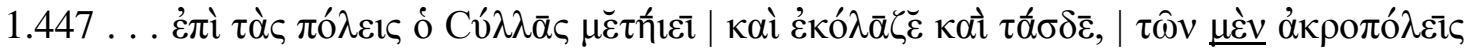

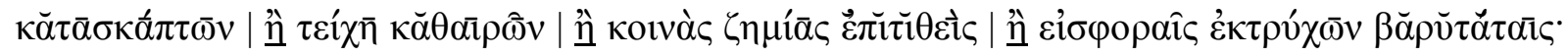

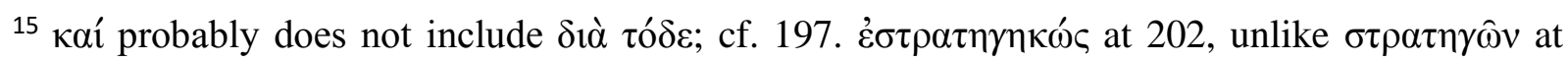
210, refers to a praetorship, cf. Them. Or. 34.34, 2.219.2-3 Downey-Norman.

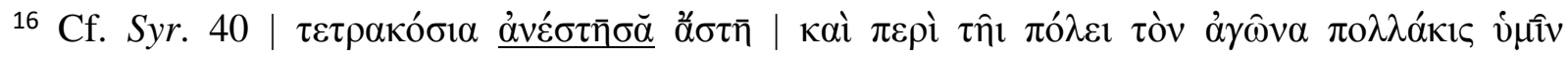
$\underline{\stackrel{\varepsilon}{\pi} \pi \bar{\varepsilon} \sigma \tau \bar{\eta} \sigma \bar{\alpha}}, \mid$, Cic. Arch. 12 neque ad communem adfērrě frūctūm | neque in aspectum lucēmquĕ prōfêrrēe, |. The parallel from Mith. 86 is not in E. Gabba, Appiani Bellorum Civilium liber primus. Introduzione, testo critico e commento con traduzione e indici ${ }^{2}$ (Florence, 1967), 254-6, or P. Goukowsky and F. Hinard, Appien, Histoire Romaine, VIII, Livre XIII, Guerres Civiles, Livre I (Paris, 2008), 190. Mith. 85, which mentions not only Sulla but the Bella Ciuilia, suggests here an ominous parallel between the two men's actions; the link perhaps even hints at Mithridates as the source for Sulla's idea on how to deal with enemies (worth considering historically, if one separates the idea of the lists?). 
|. The $\mu \varepsilon^{\prime} v$ marks the start of a new development in the sentence; the three p̆s, because the units are long enough, bring out the parallel between the four participial phrases, which all end rhythmically. The first two match each other exactly, with accusative and participle; the third adds an epithet (to an accusative of a different sort); the fourth uses a dative and puts its superlative epithet at the end. The rhythm underlines and sharpens the structure. For a similar

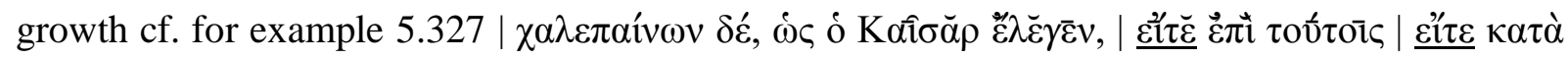

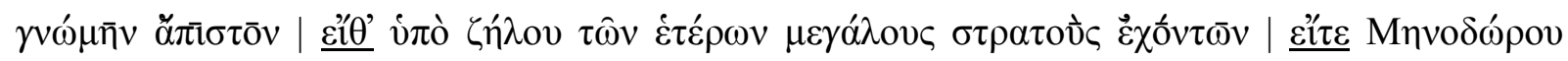

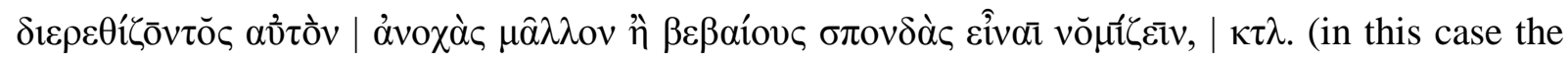

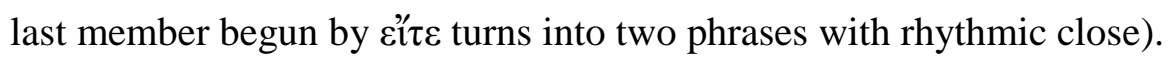

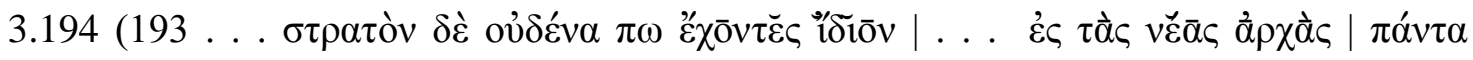

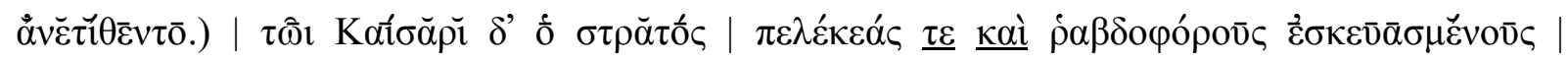

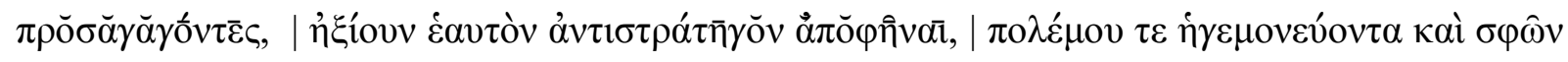

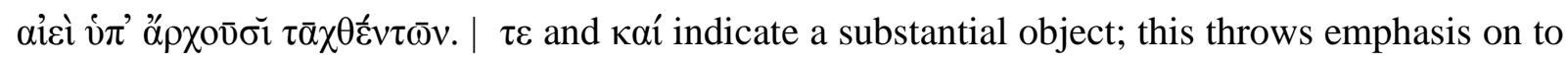

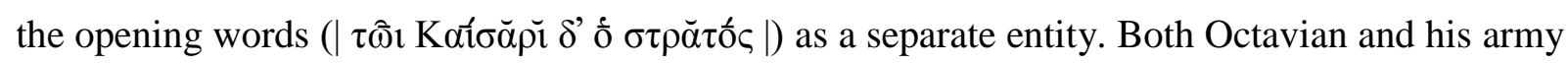
are emphasized by the context. The army's treatment of Octavian is opposed to the senate's, and they try to take his magistracy into their own hands; Octavian and army are matched in the last part of the sentence ( $\pi \mathrm{o} \lambda \varepsilon \dot{\mu} \mu \mathrm{ov} \tau \varepsilon \kappa \tau \lambda$.). Rhythm alerts the reader to the organization of the prose. ${ }^{17}$

${ }^{17}$ For doubts on the text of the last part, cf. Zerdik (n. 10), 66, and Viereck's apparatus. Hiatus after $\alpha i \varepsilon i ́ / \alpha \varepsilon^{\prime}$ is found at Pun. 623, B Civ. 2.577 and quite frequently in Plutarch; the diphthong in a rhythmic ending at $B$ Civ. 2.577 suggests the word is treated as a common one for the purposes of hiatus. On Appian's shaping of the history here in 3.194 cf. P. Goukowsky and Ph. Torrens, 


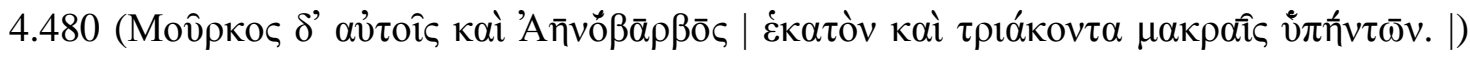

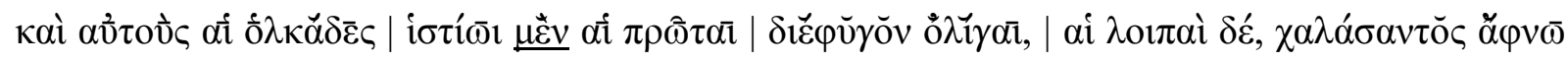

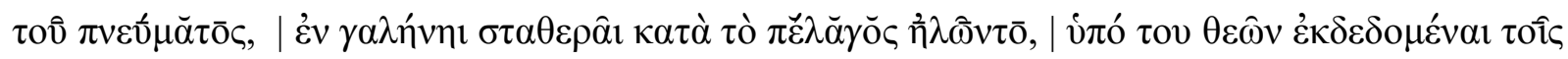

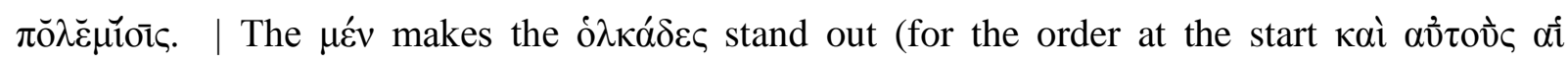

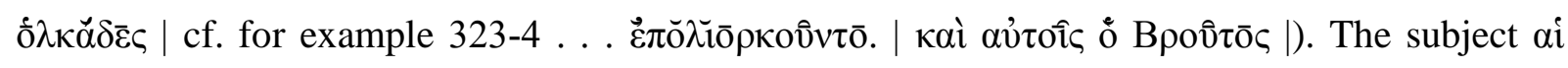
$\grave{\delta} \lambda \kappa \alpha ́ \delta \varepsilon \varsigma$ is then re-expressed as two subsets. The ó $\lambda \kappa \alpha ́ \delta \varepsilon \varsigma$ are an unmilitary sort of ship, frighteningly confronted with a large number of military craft (cf. for $\mu \alpha \kappa \rho \alpha i$ and for $\delta \lambda \kappa \alpha ́ \delta \varepsilon \varsigma$

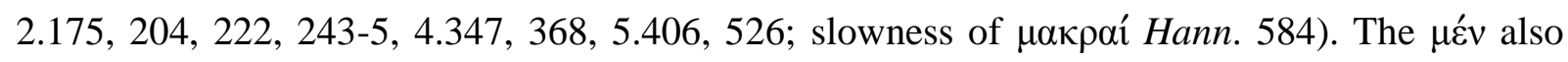
separates $\alpha i \pi \rho \hat{\omega} \tau \alpha \mathrm{l}$ as predicate; the two rhythmic closes in swift succession for the ships that

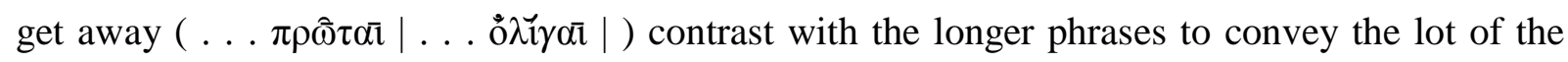
hapless ships that are becalmed. Rhythm is used expressively. ${ }^{18}$

From the examples already considered it will be apparent that what look like rhythmic closes occur frequently in each sentence. How tightly rhythmic closes can be packed in is illustrated by the phenomenon of overlapping rhythmic closes. Overlap has been suggested in Cicero; it operates through the reader or listener following one rhythmic close until that close is

Appien, Histoire Romaine X, Livre XV, Guerres Civiles, Livre III (Paris, 2010), 140-1 (one could go further).

${ }^{18}$ For the divine element at the end cf. e.g. I. Hahn, '«Appianus tacticus»', Acta Antiqua Academiae Scientiarum Hungaricae 18 (1970), 293-306, at 293-5 (thinks divine intervention very rare without a human decision as intermediary); B. Goldmann, Einheitlichkeit und Eigenständigkeit der Historia Romana des Appian (Beiträge zur Altertumswissenschaft 6, Hildesheim, Zurich, New York, 1988), 32. Giving by a god: e.g. Hann. 224. For the antithesis of ships cf. also L. Casson, Ships and Seamanship in the Ancient World (Princeton, 1971), 169. 
in turn absorbed into the start of the next. Some strong examples follow. $1.431 \mid \Lambda \alpha \mu \pi \omega$ vióc $\tau \varepsilon$. .

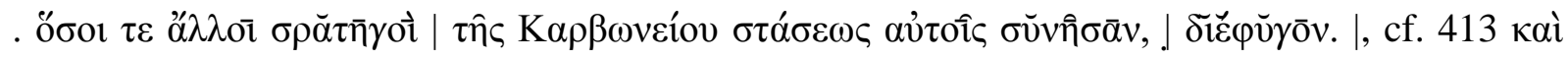

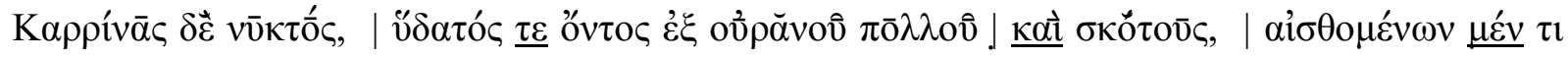

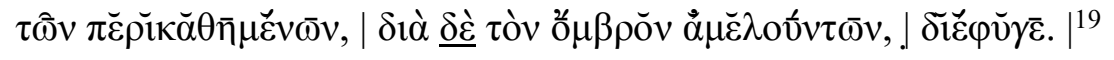

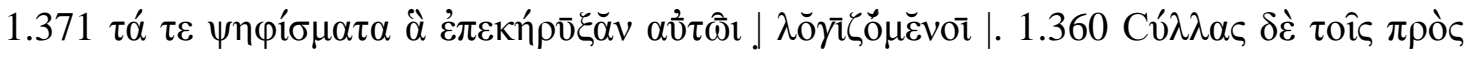

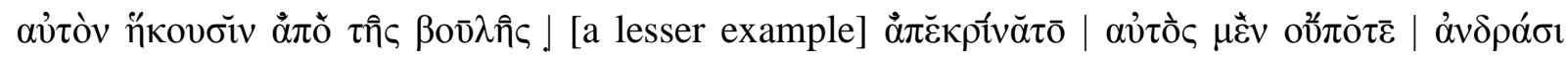

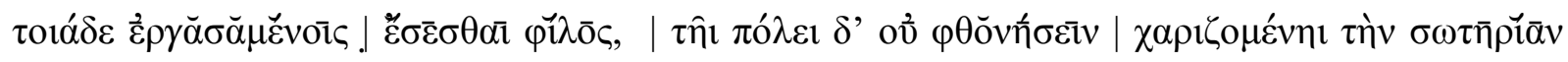

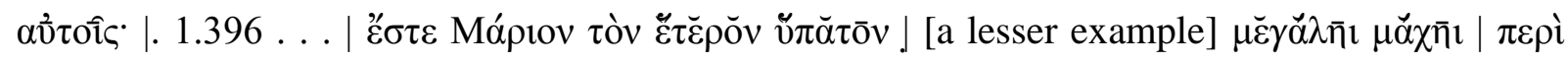
$\Pi \rho \alpha \imath \bar{\varepsilon} \sigma \tau o ั v ~ \grave{\eta} \tau \tau \eta ิ \sigma \theta \alpha \bar{\imath}\rfloor \pi \breve{v} \theta \check{\rho} \mu \breve{\varepsilon} v \bar{o} \varsigma \mid \kappa \tau \lambda$.

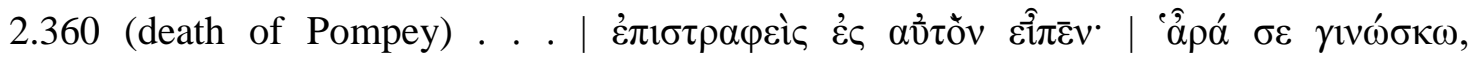

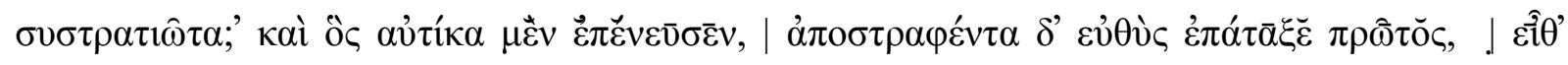

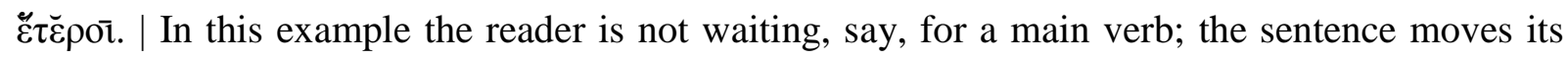
perspective when it had seemed complete. In 1.413 above, by contrast, the rhythm intensifies the movement back to the subject of the sentence in the final verb. In general in these examples rhythm underlines and heightens the structure of sentences. ${ }^{20}$

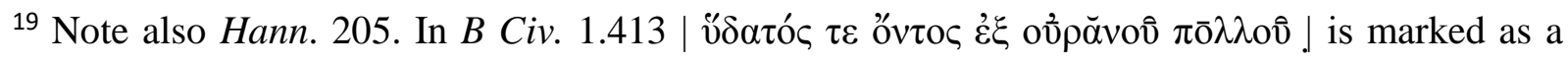
self-sufficient phrase, which is then expanded, by the intertextuality with Thuc. 2.77.6 vँ $\delta \omega \rho \dot{\varepsilon} \xi$

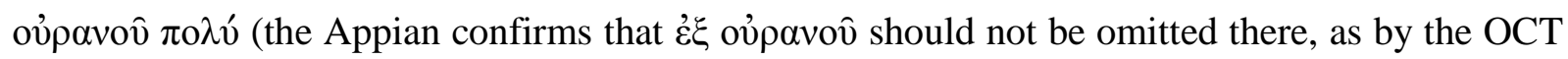
and Alberti). For overlap in Cicero see Hutchinson (n. 3), 494-6; id., 'Pope's spider and Cicero's writing', in T. Reinhardt, M. Lapidge, J.N. Adams (edd.), Aspects of the Language of Latin Prose (PBA 129, 2005), 179-93, at 181 n. 5, 184, 186, 188, 190.

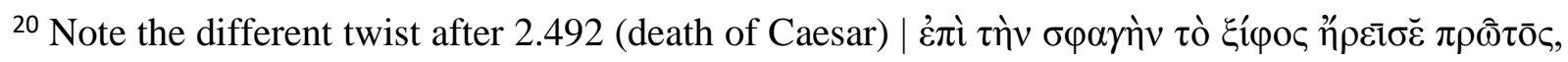
|. At Mith. 384 the next close comes before it is expected, to highlight the one-liner, marked out 
The density of rhythm varies in Appian, within the kind of limits indicated at the start of this section. This is not a sign that rhythm does not exist; rather, both density and variation can serve an expressive function. We have already seen an example (4.480, on the ships). Such features play an important role in the verbal realization of Appian's large design. It is not simply that we can accumulate enough instances to make expressiveness a plausible possibility, as we might do, say, with examples of expressive enjambement in Lucan or Statius. We can survey those places in the Civil Wars where rhythmic closes are densely packed and where at the same time unrhythmic closes are scarce. The passages, it seems, mostly contribute to the total sequence of the Civil Wars by heightening moments important to its themes or climactic in its structure. Books 2 and 3 will serve as examples. One of the two large groups of passages marks points where the civil strife of the Romans reaches peaks of action or reaction: so $2.75-7$ on the killing of Clodius and the response, 141 (second part) on terrified flight as Caesar invades, 257 (last part) on panic at Caesar's defeat, 495 (first part) on killing in the tumult at Caesar's death, 629 on Caesar's victories over the Pompeians, 3.32 (first part) emotive report of Caesar's death to Octavian. The other large group helps to highlight the movement towards monarchy: so 2.446 on Caesar's apparently kingly behaviour, 3.39-40 enthusiastic response to the new Caesar, 3.378 Octavian's entry into Rome, and various significant passages on the relation of Antony, Octavian, the soldiers and the senate (so 3.185, where Octavian is winning legions over).

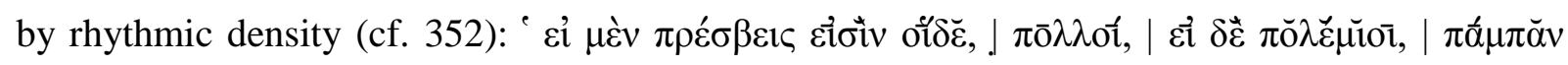
ö $\lambda$ ìyô.' | Here and at B Civ. 2.360, if these examples are accepted, what would have been a final syllable lengthened by 'metrical' pause remains short in the overlapping rhythm that surprisingly

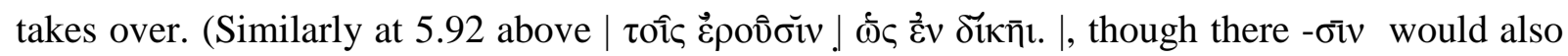
be rhythmically possible: ${ }^{----\cdots-)}$ 
Passages in speeches contribute too; they not only intensify the rhetoric but underline the issues of the work: so the matching passages 2.570 (circumstances, and beginning, of Brutus' speech) and 3.53-4 (near beginning of Octavian's speech to Antony) on the interpretation of the conspirators' deeds. ${ }^{21}$

A few examples of density (and variation) may be considered in more detail. The first is

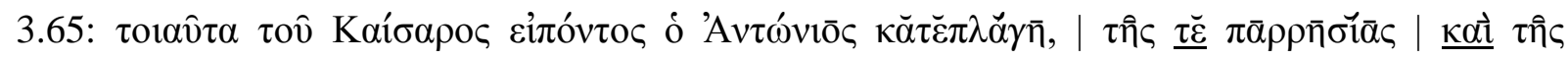

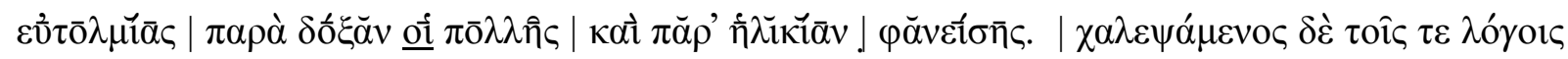

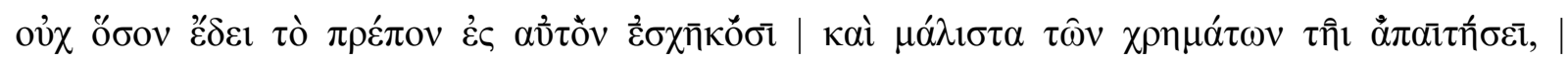

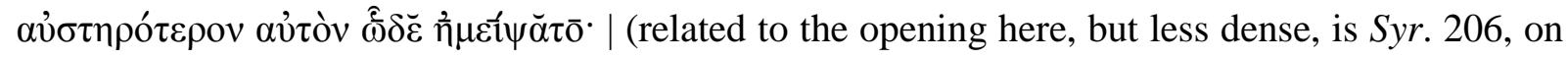
Scipio's awe-inspiring appearance). The short rhythmic phrases, marked out by prepositives and postpositives, show the impression which Octavian makes on Antony; the awed intensity fits the whole place of the future monarch in Appian's grand architecture. Longer phrases follow, on the most probable scansion; they portray the less noble reasons for Antony's chilly response. ${ }^{22}$

At 2.286, density highlights Pompey's imminent fall and his uneasy consciousness of it.

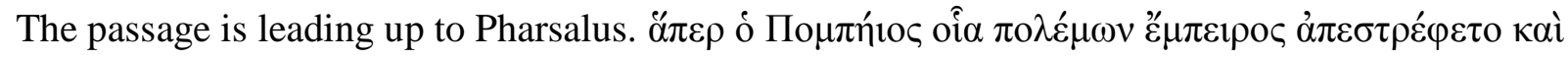

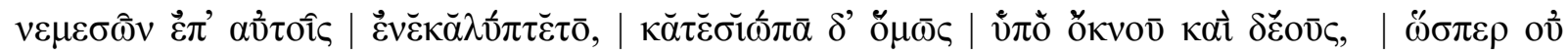

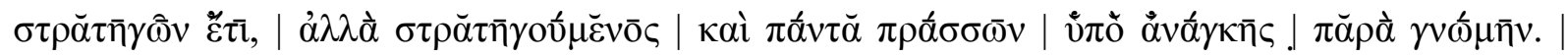

${ }^{21}$ Cf. Hutchinson (n. 3), 496-9 on density in Cicero; note too Hunter (n. 1), 84.

${ }^{22}$ Cf. A. Gowing, The Triumviral Narratives of Appian and Cassius Dio (Ann Arbor, 1992), 6670 on this meeting. For the impact of Octavian cf. also Ill. 58, with $\kappa \alpha \tau \varepsilon \dot{\varepsilon} \pi \lambda \eta \xi \varepsilon ; B$ Civ. 3.368, with $\grave{\varepsilon} \xi \varepsilon \pi \dot{\varepsilon} \pi \lambda \eta \kappa \tau o ; 371$, with $\kappa \alpha \tau \alpha \pi \varepsilon \pi \lambda \hat{\eta} \chi \theta \alpha$; 378 (mentioned above), with $\tau \varepsilon \theta \bar{\eta} \pi$ ŏ$\tau \bar{\omega} v \pi \hat{\alpha} v \tau \bar{\omega} v \mid$. On Appian's manipulation of events at Syr. 206 cf. Brodersen (n. 13), 211-12; and note e.g. Pun. 327. 


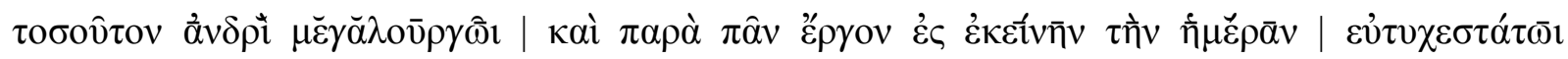

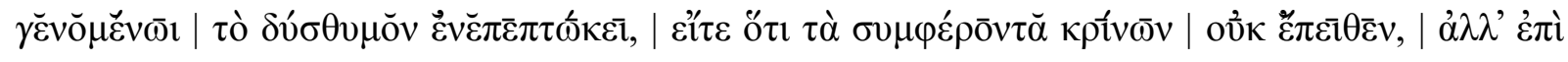

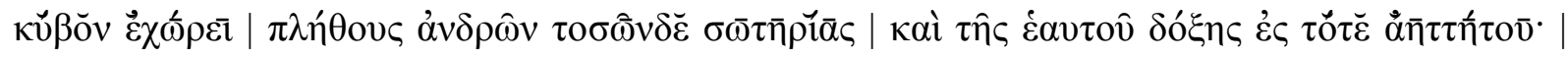

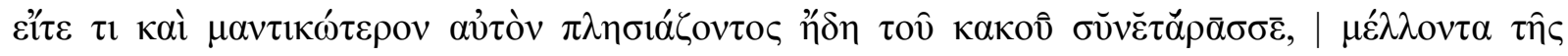

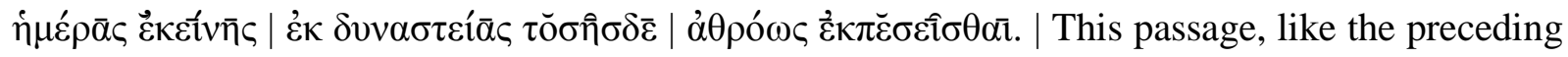
one, shows perceptible changes; its overall density remains notable. The relatively long unrhythmic start on Pompey's disdain of his imperceptive fellows is set against a more inward

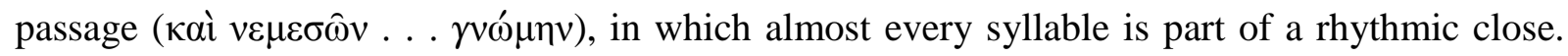

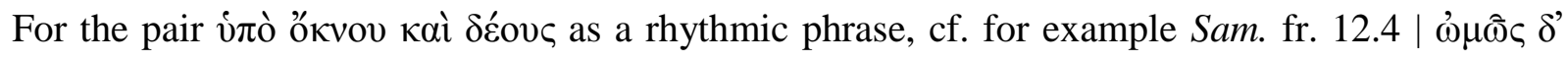

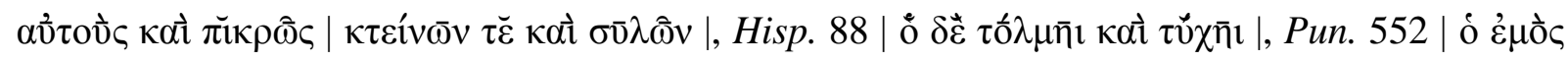

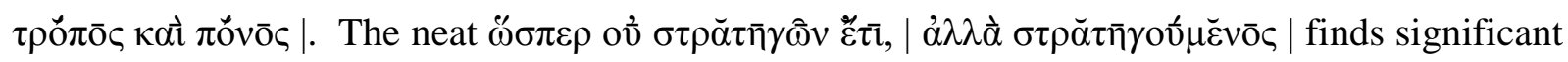

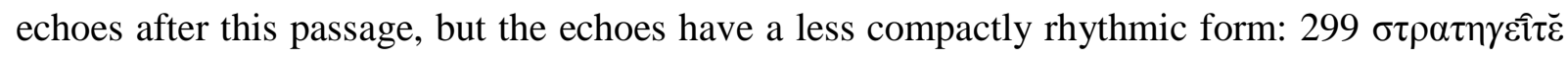

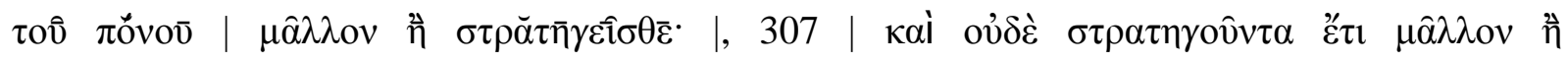

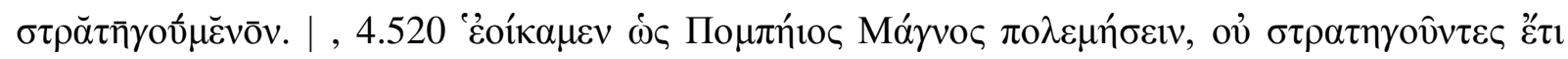

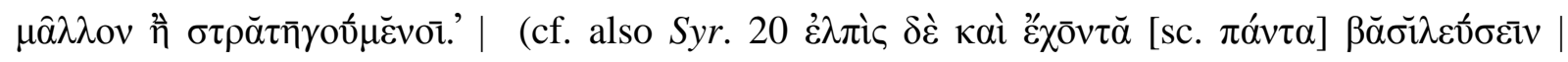

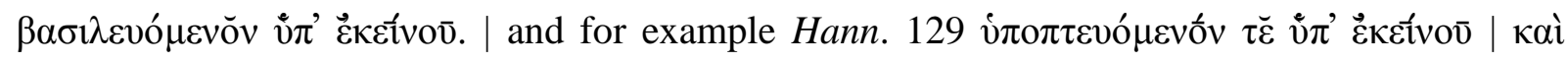

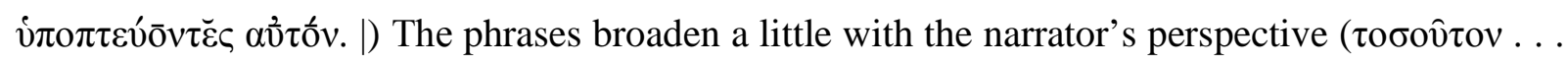

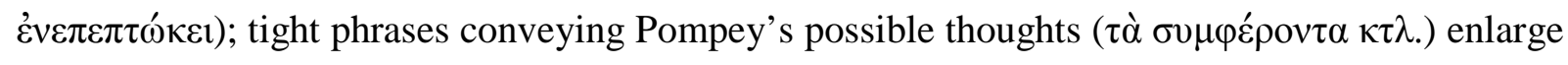
somewhat as he considers the momentousness of the occasion for his side and himself ( $\pi \lambda \hat{n} \theta$ ovৎ .

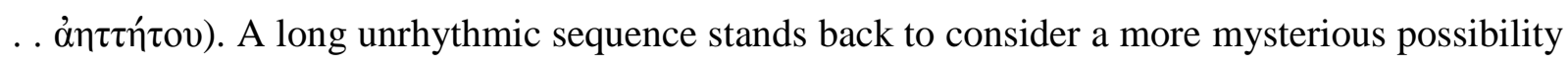

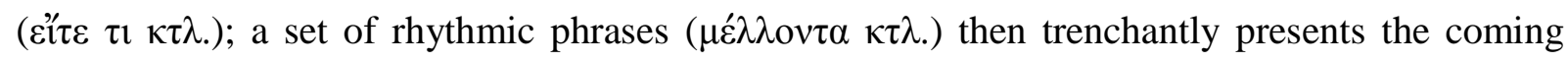
heavy and sudden fall, again a part of Appian's grand scheme (note Proem 59 on the division of the Civil Wars by generals). Such a detailed reading of the fluctuations appears to be invited by 
Appian's overall use of rhythm in the work; that use certainly indicates a connection between the density in this passage and its power within the big design.

Density can mark out vital passages that have a lower emotional temperature. So 3.370:

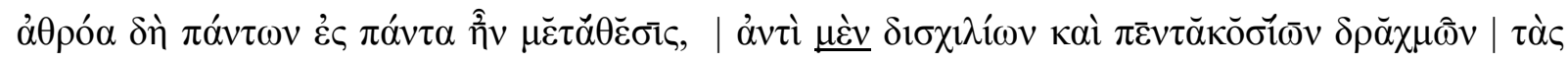

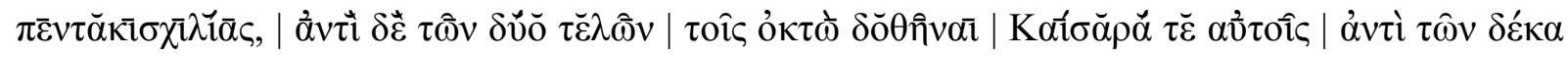

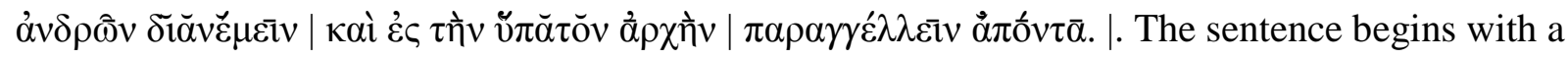
sweeping phrase on the sudden alteration in the senate's scheme ( $\dot{\theta} \theta \rho$ ó $\alpha . . \mu \varepsilon \tau \alpha \dot{\theta} \theta \varepsilon \sigma \iota \varsigma)$, and, as first item, a sum of money ( $\dot{\alpha} v \tau \grave{\imath} \ldots \delta \rho \alpha \chi \mu \hat{\omega} v)$; the rhythmic pace then quickens. Indignity attends the extraordinary and soon repented changes of mind which have been produced by Octavian's advance towards Rome (cf. 349, 355, 357, 364). The final clause and word provide a remarkable culmination. This passage too shows the rise of Octavian and the progress towards monarchy (cf. 371).

The three passages exemplify the connection between Appian's shaping on a massive scale and on a small one. Scholars are now, as we glimpsed earlier, more aware of Appian's large and pervasive structuring; we should endeavour to consider how that structuring is implemented on the level of style. ${ }^{23}$

${ }^{23}$ For the general possibility note F.J. Gómez Espelosín, 'Estrategias narrativas en la Historia de Apiano: algunos ejemplos', Annali della Scuola Normale Superiore di Pisa Ser. IV, 1.1 (1996), 103-117, at 117, 'Su obra obedecía a un diseño artístico particular . . . , para cuyo completo desarrollo se sirvió de determinadas estrategias narrativas y unos procedimientos estilísticos.' Architecture on the scale of a book (or most of one): Brodersen (n. 13), 232-6, cf. id., 'Appian und sein Werk', ANRW 2.34.1 (Berlin and New York, 1993), 339-63, at 359 (even saying [358], 'Tatsächlich gliedert Appian das Material geradezu rhythmisch, etwa wenn . . .'); C. Leidl, 
As this section has started to indicate, the realization that Appian is rhythmic, and that rhythm runs right through his sentences, should transform our view of him as a writer. His writing now reveals itself as expressive and pointed, in the service both of local impact and argument and of an immense edifice. We will need to engage more responsively with the specifics of his writing: they are a fundamental part of his literary creation.

\section{IMPERIAL GREEK PROSE: PROSPECTS}

Appians Darstellung des 2. Punischen Krieges in Spanien (Iberike c. 1-38 § 1-158a). Text und Kommentar (Münchener Arbeiten zur Alten Geschichte 11, Munich, 1996), 300-4. On B Civ.: D. Magnino, 'Le “Guerre Civili”" di Appiano', ANRW 2.34.1 (Berlin and New York, 1993), 52354 (building on, but more positive than, E. Gabba, Appiano e la storia delle guerre civili [Florence, 1956]). Of the whole work (thematically): Goldmann (n. 18); G.S. Bucher (2000), 'The origin, program, and composition of Appian's Roman History', TAPhA 130 (2000), 411-58 (with attention to the process of composition, which is perfectly compatible with perception of an evolving design; for monarchy cf. esp. 431-6, and Brodersen [above, 1993], 356). Unity on level of military analysis and character of generals: Hahn (n. 18). Studies of moral and military shaping in individual episodes: e.g. E. Potz (n. 2), and id. (1998), 'Appians Klio dichtet: Die Curio-Episode bei Appian (E 2,44, 175-45, 185) und Caesar (b.c. II 23-44)', Philologus 142 (1998), 293-9; G.S. Bucher, 'Fictive elements in Appian's Pharsalus narrative', Phoenix 59 (2005), 50-76. 
If the significance of the subject is allowed for Appian, investigation and study of more authors would seem desirable (I hope to carry some out). But which authors? It would need much more work to attain a full knowledge of how far rhythmic prose extends in the Imperial period; but the discussion so far will enable us to form some preliminary ideas. We will return to the set of 20 sentences each from authors who are unlikely to be rhythmic. They could provide a point of comparison for samples of 20 sentences from Imperial authors, each of whom might or might not be rhythmic. If the pre-Imperial set were an instance of 'normal' distribution, that would add precision to our comparison. We could then work out for this set a sample standard deviation $(s)$ from the mean $(\mu): \mu$ would be the mean number of sentences out of 20 which would, if the author were following the later system, close rhythmically. This pre-Imperial $s$ could then be used to measure the Imperial writers. To produce it, we would find $\mu$, add together the square of the differences of each example (each 20) from $\mu$, divide by the total of examples -1 , and obtain the square root. Initially, we could get a better idea of the distribution with more examples; so we could break the 400 random sentences up into 100 groups of 4.2 of these groups show 0 sentences that would close rhythmically, 15 show 1,29 show 2,40 show 3,14 show 4 . $\mu$ is 2.49 , $s$ is 0.9795381307 .2 groups would fall below $\mu-2 s$ (i.e. $\mu-(2 \times s)), 15$ within $\mu-2 s, 29$ would be within $\mu-s$, 40 within $\mu+s$, 14 within $\mu+2 s$. The general structure and the percentages in the categories $(\mu+$ or -$) s, 2 s, 3 s$ roughly resemble those of a normal distribution (within $s: 69 \%$; within $2 s$ : $98 \%$; within $3 s: 100 \%$; expected: about $68 \%, 95 \%, 99.7 \%)$. The 29 and 40 depart in a limited way from the symmetry of the Gaussian curve which depicts normal distribution; that departure might easily be rectified with a sample statistically more adequate than 100 (29 is $72.5 \%$ of 40 ). At all events, we could now hypothesize $s$ for the 20 pre-Imperial groups of 20 , 
not to prove anything, but as a means of articulating the divergence between the pre-Imperial list and samples of 20 from some Imperial writers. ${ }^{24}$

Samples of 20 sentences were assembled from Achilles Tatius, Aelius Aristides, Alexander of Aphrodisias (De Anima, De Fato, De Mixtione), Appian (Bella Ciuilia), Arrian, Cassius Dio, Chariton, Clement, Dio of Prusa, Epictetus/Arrian, Galen, Hebrews, Heliodorus, Herodian the historian, Josephus, Longinus, Longus, Lucian, Maximus of Tyre, Pausanias, Philo, Philostratus (narrative parts of Vitae Sophistarum; separate sample for quotations from speeches), Plotinus, Plutarch, Polemon, Theon, Xenophon of Ephesus. In some cases, separate samples of 20 were taken from different works or groups of works. It may be remembered that no author in the pre-Imperial set showed more than 14 rhythmical closes out of 20 , a point which would lie just beyond $(\mu=12.45+)$ hypothesized $s$, that is 13.98811231. Of the Imperial authors, Cassius Dio, Herodian, and some works of Galen showed 16, beyond the hypothesized preImperial $2 s$ (15.5622462); Achilles Tatius, Alexander of Aphrodisias, Chariton, some Galen, Longinus, Philo, Polemon: 17, just within $3 s$ (17.06433693); Appian, Josephus, Bellum Judaicum and Contra Apionem (not the Antiquitates), Longus: 18, beyond $3 s-$ a significant boundary, if we have to do with a normal distribution for the pre-Imperial authors; Plutarch's declamatory De Fortuna Romanorum: 19, beyond 4s (18.60244924).

For each of these authors singly (Herodian, etc.), the result is notable: in a normal distribution, about $95 \%$ would be within $2 s$, so results of 16 already prompt more investigation.

\footnotetext{
${ }^{24}$ For the mean and the sample standard deviation, see M. Samuels, J. Witmer, A. Schaffner, Statistics for the Life Sciences (Harlow, 20144), 63-4, 82-4, 87-8; J.E. Freund and B.M. Perles, Modern Elementary Statistics (Upper Saddle River, NJ, 2007²), 74-93. For the normal distribution, see Samuels, Witmer and Schaffner, 155-81.
} 
(A result below 15 should not preclude it for other authors.) In those cases where there has been some earlier research, it confirms the idea that the author is rhythmic. Together the results for all these authors (Herodian, etc.) suggest much rhythmic writing in the period, with intriguing generic and other connections. The prominent place of historiography forms a contrast with Roman historiography, where Sallust, Livy, and Tacitus (Histories, Annals, Agricola, Germania) stand out from their times in not writing rhythmically. But there also exists Greek historiography in the Imperial period which is unlikely to be rhythmic. So Arrian's Anabasis contrasts with Herodian, etc.: a sample showed 9 out of 20, strikingly low within the whole group of Imperial authors sampled, and below $2 s$. Narrative obviously connects historiography with the novel. Achilles Tatius, Chariton, and Longus look rhythmic on the present basis; Xenophon of Ephesus may have reached us in an abridged form; the late Heliodorus is the other author who presents us with 9. The position with rhetoric appears complicated; the Hellenistic material would have suggested it was the first place to look. It was indeed where some earlier scholars looked. ${ }^{25}$

${ }^{25}$ Cf. n. 1 (Norden, Wilamowitz). See Heibges (n. 1) for Chariton, Josephus (105-8), and Polemon (83-91); for Philo De Groot (n. 1, 1921), 63-4, (n. 1, 1926), 34-5 and Winterbottom (n. 1), 264; for Longus De Groot (n. 1, 1926), 35, Hunter (n. 1), 84-5; for Longinus Wilamowitz (n. 1), 259 n. 1 ('Ein Bösenwilliger könnte manche Klauseln asianisch nennen wollen.'), D.A. Russell (n. 3), 196-7. On Roman historiography cf. G.O. Hutchinson, Greek to Latin: Frameworks and Contexts for Intertextuality (Oxford, 2013), 238-40. As for rhetoric and its traditions, one exercise (P.Oxy. XLV 3235 [ $3^{\text {rd }}$ cent. AD]) looks rhythmic in what we have (the proper names in fr. 2 col. ii 5-6 notwithstanding); but the sample is much too small for us to be sure. For the Hellenistic material see recently D. Papanikolaou, 'The Aretalogy of Isis from Maroneia and the question of Hellenistic “Asianism”, ZPE 168 (2009), 59-70. 
One would get further with an $s$ which was smaller in proportion to the numbers in each example, that is with a larger number of sentences in each; to see the possibilities, one may experiment with 50 sentences each (one could get a hypothetical $s$ for 8 groups of 50 in the preImperial writers and add a further 2 groups from Lysias). Of two samples of 50 sentences from Plutarch's Lives, one is beyond the pre-Imperial $2 s$, one well beyond $3 s$, of two samples of 50 from the Moralia, both are beyond $s$ and within $2 s$. So far the Lives look to be rhythmic, and to have a higher proportion of rhythm than the Moralia. A sample of 50 from Galen's less technical writing takes us well beyond $4 s$, a sample of 50 from his more technical writing is within $s$. There look to be important distinctions within writers' $x u v r e s$. Across authors, the use of rhythm would serve different functions; thus the use in Plutarch's Lives would differ from that in Appian. Plutarch's use would, for instance, highlight the imaginative richness of his vocabulary, so unlike Appian's forcefully restricted and recurring words and phrases. These different stylistic functions would relate to differences in thought and large structure. It looks as if rhythmic writing is a feature which should affect our overall vision of the literary landscape in this period; it has also emerged as a means of expression and articulation which should influence our reading of rhythmic texts. Both aspects are important incitements to investigating further. ${ }^{26}$

${ }^{26}$ For Plutarch's Lives cf. De Groot (n. 1, 1919), 1-6, 12-13, 42-54, 1926, 35-6; on the Moralia, F.H. Sandbach, 'Rhythm and authenticity in Plutarch's Moralia', CQ 33 (1939), 194-203. Plutarch is an obvious point of comparison with Appian, and was probably so for Appian himself (his fame is implied e.g. by his appearance in the first chapter of Gellius' Noctes Atticae; add to the papyri P. Gen. inv. 477 and 504 [2 $2^{\text {nd }}$ or $3^{\text {rd }}$ cent. AD], M. Bagnoud, S. Gindrat, V. Monteventi, S. Nasel, Th. Schmidt, 'Nouveaux fragments d'un papyrus de la Vie de César de Plutarque (P. Gen. inv. 477 et 504)', MH 70 [2013], 10-15). Vatic. Pal. 2 puts the comparison of Caesar and 
Alexander which ends Bella Ciuilia 2 after Plutarch's pair Alexander and Caesar: M. Manfredini, 'Un nuovo testimone di Appiano in un codice di Plutarco', Annali della Facoltà di Lettere e Filosofia dell'Università di Napoli, 20 (n.s. 8, 1977-8), 105-8. Appian's vocabulary cannot be discussed here; but it should once more be seen in relation to his structures. Scholarship on Racine suggestively illustrates how the restriction of vocabulary can contribute to impact and the charging of words: cf. J.-G. Cahen, Le Vocabulaire de Racine (Paris, 1946), Ch. Bernet, Le Vocabulaire des tragédies de Jean Racine : analyse statistique (Travaux de linguistique quantitative 12, Geneva and Paris, 1983; note 104-6 on Racine and Corneille), M.G. Pittaluga, Aspects du vocabulaire de Jean Racine (Biblioteca della ricerca: Cultura straniera 40, Fasano and Paris, 1991), B. Louvat, 'Le Vocabulaire à l'épreuve de la langue : l'exemple d'Andromaque', La Licorne 50 (2009) (http://licorne.edel.univ-poitiers.fr/document4394.php). 